口腔悪性腫瘍患者における HTLV-I の浸淫と免疫抑制機能に関する研究

\author{
国芳秀晴
}

\title{
Prevalence of HTLV-I infection and immunosuppression in patients with oral malignant tumors
}

\author{
Hideharu KUNIYoshI
}

\begin{abstract}
Adult T-cell leukemia (ATL) patients are frequently associates with other malignancies. To elucidate the possible association of HTLV-I infection with the tumorigenesis of oral malignancies in Kagoshima prefecture, I analyzed the correlation between HTLV-I and the patients with oral malignant tumor (OMT). The following results were obtained;

1) The organ distribution of oral malignancies in Kagoshima prefecture was found in the tongue most frequently. The male to female sex ratio was 2 to 1 and the age distribution of the highest incidence ranged from 60 to 80 years. The most frequently observed histopathology was the squamous cell carcinoma (74/78 cases).

2) HTLV-I seropositivity of OMT in total, was 2.3 times more than that of normal adults in Kagoshima prefecture and the male to female sex ratio was 4 to 3 .

3) HTLV-I provirus was detected in 5 cases of 7 peripheral blood lymphocytes (PBLs) donors of the seropositive OMT.

4) OMT was associated with HLA-DRw8 in significantly high frequency $(\mathrm{cp}<0.05)$.

5) The strength of T-cell immune response to HTLV-I and Phytohemagglutinin P(PHA) was observed in order of normal controls $>$ seronegative OMT $>$ seropositive OMT. The autologous proliferative response (APR) ${ }^{21)}$ of PBLs was detected in 9 cases of 14 seropositive OMT, indicating immunological abnormality associated with HTLV-I infected OMT.

6) When T-cell subset in the seropositive OMT were analyzed after the culture of PBLs, CD4/8 ratio was segregated to 2 groups, one with an increased $\mathrm{CD} 4 / 8$ ratio (3 cases) and the other with a decreased $\mathrm{CD} 4 / 8$ ratio ( 7 cases). The former produced poor prognosis and the latter a good prognosis.

In conclusion, OMT infected with HTLV-I had a tendency of less immune response to HTLV-I and PHA compared with those of seronegative controls. The CD4/8 ratio was primarily associated with the prognosis of OMT. OMT had HLA-DRw8 in significantly high frequency comparing with the normal population. Thus, HLA-DRw8 and HTLV-I infection may interact each other and modulate the host immune system against OMT.
\end{abstract}

Key words: oral malignant tumors (口腔悪性腫瘍), HTLV-I infection (HTLV-I 感染), immunosuppression (免疫抑制)

鹿児島大学歯学部第一口腔外科学教室

(主任：山下佐英教授)

First Department of Oral and Maxillofacial Sur- gery, Kagoshima University Dental School (Chief: Prof. Sukehide Yamashita)

受付日：昭和63年12月 8 日 
目

次

I 緒 言

II 研究対象ならびに方法

1. 研究対象

2. 研究方法

（1）患者血清およびリンパ球の分離

(2) 抗 HTLV-I 抗体の測定

（3）患者末梢血リンパ球 (PBLs) からの HTLV-I プロウイルス DNA の検出

(4) HLA タイピング

（5）患者 PBLs の細胞性免疫能の分析

III 研究結果

（1）鹿児島県における口腔悪性腫瘍患者の属性の検 討

（2）口腔覀性腫瘍患者に抢ける抗 HTLV-I 抗体の 保有状況

（3）口腔悪性腫湯患者の PBLs からの HTLV-I プ ロウイルス DNA の検出

（4）口腔悪性腫瘍患者に関連する HLA の検索

（5）口腔覀性腫瑒患者の HLV-I に対する免度応 答性

（6）口腔悪性腫惶患者の非特異的免疫応答能と $\mathrm{T}$ 細 胞サブセットの解析

IV 総括ならびに考察

（1）鹿児島県における口腔悪性腫瘍患者の属性の検 討

（2）口腔悪性腫愓患者に打ける抗 HTLV-I 抗体の 保有状況

（3）口腔恶性腫瘍患者の PBLs からの HTLV-I プ ロウイルス DNA の検出

（4）口腔覀性腫湯患者に関連する HLA の検索

（5）口腔悪性腫場患者の HTLV-I に対する免疫応 答性

（6）口腔悪性腫瘍患者の非特異的免疫応答能と $\mathrm{T}$ 細 胞サブセットの解析

$\mathrm{V}$ 結 語

\section{I. 緒言}

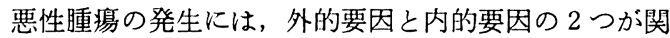
与していると考えられている，前者には生活環境に存在 する癌原性物質, 放射線などの物理化学的因子1) のほか に，癌ウイルス22などの生物学的因子が含まれており，

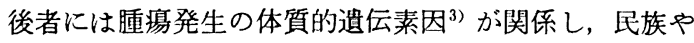
家系によって異なった素因が知られている。これらの外 因と内因は，相互に作用して腫湯の発生にかかわってい

ることが考えられている．以上のらちウイルス性腫痬に ついては, 近年, 分子遺伝学的メカニズムについての解
折が著しく進歩してきた4) ウイルス性腫㳷にはバーキ ットリンバ腫(), 乳頭腫 ${ }^{6)}$, 成人 $\mathrm{T}$ 細胞白血病 (以下 ATL と略す) などが知られており，宿主細胞遗伝子の活性 化と発癌との関係が示唆されている。 このらち, ATLの 原因ウイルスである Human T-cell leukemia virus type I (以下 HTLV-I と略す) ${ }^{8)}$ は日本の南西部, アフリ カ，カリブ海周辺諸国に高度に浸淫し ${ }^{9 \sim 11)}$, 白血病》な

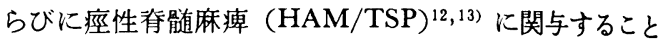
が知られている. Asou らの報告 ${ }^{14)}$ にるる，膀胱癌患

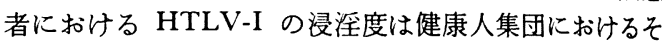
れの 5 倍強, 頭頸部悪性腫場では 4 倍強であることが明

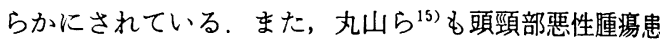
者の5ち HTLV-I ウイルスキャリアは ATL 多発地域 である 沖縄県では 5 倍，ATL 非多発地域である千葉県 でも高率であり，しかも，臓器特異性はなく種々の癌患 者で全般的に HTLV-I キャリアが多かったと報告して いる。鹿児島県はATL 多発地区であり，HTLV-I ウ

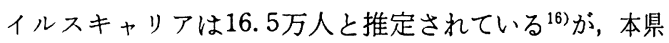
に捕ける悪性腫瘍患者での HTLV-I 浸淫の実態は，ま だ明らかにされていない，近隣の各地でみられる ATL 之固型癌の 合併例 $\left.{ }^{17} 20\right)$ と同様な症例が多数存在寸る可 能性がある。

最近, 宇宿・園田らは，ATL 患者の HLA は特異な 型別を示し免疫遺伝学的背景が平均的日本人とは異なっ ていることを報告している ${ }^{21)}$. この HLA 抗原は七卜第 6 染色体短腕に存在する組織適合性抗原を代表する分子 であり, 贜器移植での適合性, 免度生体防御での異物識 別, 疾患感受性の素因などに関連して重要な機能を有す るといわれ，親から子に優性遗伝する形質である222.

そこで，著者は口腔悪性腫湟の発症に関する外的要因 の一つとして HTLV-I ${ }^{8)}$ の関与に着目し，また，内的 要因として HLA に連鎖した遗伝素因 ${ }^{22}$ に注目しこれ らと口腔恶性腫瑒の発症との関係を検索した。

\section{II. 研究対象ならびに方法}

\section{1. 研究対象}

昭和 62 年 1 月から 12 月までに鹿児島大学歯学部第一口 腔外科学教室外来执よび病室で治療中の口腔悪性埂場患 者のうち，鹿児島県内に本籍をおく78例の患者を対象と して研究を行った（表 1 ）。非口腔覀性腫場患者対照群

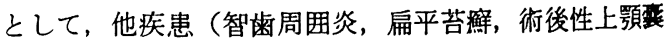
胞, 上下顎骨骨折, プランマービンソン症候群, 唾石 症, 唾液腺炎, 異物による炎症) の外来患者 8 例を対象 として用いた。これらの患者の輸血歴の有無について は，本人からの問診により聴取した。

\section{2. 研究方法}

（1）患者血清およびリンパ球の分離

対象患者の末梢静脈血を本人の同意のもとに採血し， 
表 1 対象患者の属性分布

\begin{tabular}{|c|c|c|c|c|c|c|c|c|c|c|c|}
\hline ID-No. & 性別 & 年䊀 & 診 断 名 & 輸血 & 病理組織像 & ID-No. & 性別 & 年齢 & 誩 断 名 & 輸血 & 病理組織像 \\
\hline 001 & 男 & 60 & 舌 癌 & 無 & 扁平上皮癌 & 040 & 男 & 64 & 頓粘膜癌 & 無 & 扁平上皮痁 \\
\hline 002 & 男 & 62 & 舌 癌 & 無 & 扁平上皮瘦 & 041 & 男 & 81 & 煩粘膜湼 & 無 & 扁平上皮瘤 \\
\hline 003 & 男 & 78 & 舌 癌 & 無 & 扁平上皮㾔 & 042 & 男 & 54 & 頓粘膜痹 & 無 & 扁平上皮癌 \\
\hline 004 & 男 & 77 & 舌 癌 & 無 & 扁平上皮癌 & 043 & 男 & 81 & 煩粘膜癌 & 無 & 粘表皮瘐 \\
\hline 005 & 男 & 58 & 舌 痹 & 無: & 扁平上皮癌 & 044 & 男 & 72 & 上原癌 & 無 & 原平上皮癌 \\
\hline 006 & 男 & 51 & 舌 癌 & 無 & 扇平上皮癌 & 045 & 男 & 75 & 下唇癌 & 無 & 扁平上皮癌 \\
\hline 007 & 男 & 75 & 舌 癌 & 無 & 扁平上皮癌 & 046 & 男 & 58 & 下唇癌 & 無 & 扁平上皮癌 \\
\hline 008 & 男 & 51 & 舌 癌 & 無 & 扁平上皮癌 & 047 & 男 & 71 & 下唇癌 & 無 & 扇平上皮痁 \\
\hline 009 & 男 & 64 & 舌 癌 & 無 & 扁平上皮癌 & 048 & 男 & 32 & 上顎萡肉癌 & 無 & 扁平上皮癌 \\
\hline 010 & 男 & 61 & 舌 癌 & 無 & 扁平上皮癌 & 049 & 男 & 67 & 下顎菻肉癌 & 無 & 扁平上皮癌 \\
\hline 011 & 男 & 53 & 舌 癌 & 無 & 扁平上皮瘦 & 050 & 男 & 59 & 下顎歯肉癌 & 無 & 扁平上皮癌 \\
\hline 012 & 男 & 71 & 舌 癌 & 無: & 扁平上皮癌 & 051 & 男 & 60 & 下顎蓶肉癌 & 無 & 扁平上皮癌 \\
\hline 013 & 男 & 70 & 舌 癌 & 無 & 扁平上皮癌 & 052 & 男 & 51 & 覀性リンパ腫 & 無 & 悪性リンパ腫 \\
\hline 014 & 男 & 70 & 舌 㿋 & 無 & 扁平上皮癌 & 053 & 男 & 62 & 䖩性黑色腫 & 無 & 悪性黒色腫 \\
\hline 015 & 男 & 67 & 舌 癌 & 無 & 扁平上皮癌 & 054 & 男 & 62 & 耳下腺瘦 & 無 & 腺栚慗胞癌 \\
\hline 016 & 男 & 66 & 舌 癌 & 無 & 㕃平上皮癌 & 055 & 女 & 36 & 舌＼cjkstart癌 & 無 & 扁平上皮癌 \\
\hline 017 & 男 & 48 & 舌 癌 & 無 & 扁平上皮癌 & 056 & 女 & 72 & 舌 癌 & 無 & 扁平上皮癌 \\
\hline 018 & 男 & 63 & 舌 癌 & 無 & 扁平上皮癌 & 057 & 女 & 72 & 舌 癌 & 無 & 扁平上皮癌 \\
\hline 019 & 男 & 67 & 舌 癌 & 無 & 扁平上皮癌 & 058 & 女 & 77 & 舌 痹 & 無 & 扁平上皮癌 \\
\hline 020 & 男 & 75 & 舌 痹 & 無 & 骗平上皮癌 & 059 & 女 & 64 & 舌 癌 & 無 & 扁平上皮癌 \\
\hline 021 & 男 & 59 & 口底㿋 & 無 & 扁平上皮癌 & 060 & 女 & 30 & 舌 癌 & 無 & 扇平上皮癌 \\
\hline 022 & 男 & 59 & 口底癌 & 無 & 扁平上皮癌 & 061 & 女 & 73 & 舌 癌 & 無 & 扁平上皮癌 \\
\hline 023 & 男 & 50 & 口底癌 & 有 & 扁平上皮癌 & 062 & 女 & 82 & 舌 癌 & 無 & 扁平上皮癌 \\
\hline 024 & 男 & 72 & 口底癌 & 無 & 扁平上皮癌 & 063 & 女 & 67 & 舌 癌 & 無 & 扁平上皮癌 \\
\hline 025 & 男 & 63 & 口底癌 & 無 & 扁平上皮癌 & 064 & 女 & 51 & 舌 癌 & 無 & 扁平上皮癌 \\
\hline 026 & 男 & 63 & 口底癌 & 無 & 扁平上皮痹 & 065 & 女 & 76 & 舌 癌 & 無 & 扁平上皮癌 \\
\hline 027 & 男 & 59 & 口底癌 & 無 & 扁平上皮癌 & 066 & 女 & 47 & 舌 癌 & 無 & 扁平上皮痹 \\
\hline 028 & 男 & 73 & 口底癌 & 無 & 扁平上皮癌 & 067 & 女 & 69 & 口底癌 & 無 & 扇平上皮癌 \\
\hline 029 & 男 & 79 & 口底癌 & 無 & 扁平上皮癌 & 068 & 女 & 61 & 口底㿔 & 無 & 扁平上皮癌 \\
\hline 030 & 男 & 72 & 口底癌 & 無 & 扁平上皮癌 & 069 & 女 & 50 & 下顎㴹肉癌 & 無 & 扁平上皮瘦 \\
\hline 031 & 男 & 57 & 口底癌 & 無 & 扁平上皮癌 & 070 & 女 & 77 & 下顎䔥肉癌 & 無 & 扇平上皮癌 \\
\hline 032 & 男 & 68 & 口底癌 & 無 & 扁平上皮癌 & 071 & 女 & 62 & 下顎迷肉癌 & 有 & 扁平上皮癌 \\
\hline 033 & 男 & 64 & 口底癌 & 無 & 扁平上皮癌 & 072 & 女 & 77 & 頓粘膜癌 & 無 & 扁平上皮癌 \\
\hline 034 & 男 & 54 & 口底癌 & 無 & 扁平上皮癌 & 073 & 女 & 71 & 煩粘膜癌 & 無 & 扁平上皮癌 \\
\hline 035 & 男 & 64 & 口底癌 & 有 & 扁平上皮癌 & 074 & 女 & 61 & 煩粘膜癌 & 無 & 原平上皮癌 \\
\hline 036 & 男 & 83 & 下買茵肉癌 & 無 & 扁平上皮癌 & 075 & 女 & 62 & 下唇癌 & 無 & 扁平上皮癌 \\
\hline 037 & 男 & 74 & 下顎崊肉癌 & 無 & 扁平上皮癌 & 076 & 女 & 48 & 上顎葜肉癌 & 無 & 扇平上皮癌 \\
\hline 038 & 男 & 73 & 下顎宩肉癌 & 無 & 扁平上皮癌 & 077 & 女 & 59 & 上顎㳡肉癌 & 無 & 扁平上皮瘦 \\
\hline 039 & 男 & 45 & 下靧隧肉癌 & 無 & 扁平上皮癌 & 078 & 女 & 78 & 上顎㴹肉癌 & 無 & 扁平上皮癌 \\
\hline
\end{tabular}

常法により血清を分離し $-20^{\circ} \mathrm{C}$ 保存, 用時検体とした。 リンパ球の分離はへパリン(ノボヘパリン：ノボインダ ストリー A/S) 加末梢静脈血を採取し,ダルベッコの燐 酸緩衝液 (以下 PBS と略す) で 2 倍希釈したのち, Böyum の変法 ${ }^{23)}$ を用いて行った。分離されたりンパ球
(PBLs) は皮冷下で30\%ウシ胎児血清（以下 FCS, Flow Labs.) 加 RPMI 1640 に $1 \times 10^{7} / \mathrm{ml}$ となるように浮遊 させたのち, 等量のジメチルスルホキシド(以下 DMSO) を含む培地の冷 $20 \%$ DMSO-10\%FCS-RPMI 1640 を段階的 $(50 \mu \mathrm{l} / \mathrm{sec})$ に添加 し，終濃度 $10 \% \mathrm{DMSO}$ 
A

ヘペリン加末梢血
Ficoll-Conray 比重

遠心分離法 $(\mathrm{D}: 1.077)$

一次培率 (6 日間)

Percoll 比重遠心分

離法 $(30 \%$ ～55\%)

二次培数 (20日間)

醉素処理 (TEN-Proteinase $\mathrm{K}, 50^{\circ} \mathrm{C}, 3$ 時間)

フェ,$\frac{\downarrow}{\downarrow}$ ル抽出 (Phenol : Chloroform $=1: 1$ )

2 倍量のエタルール液

(ethanol : acetate buffer $(\mathrm{pH} 5.5)=9: 1$ ) 添加 1

クラスマイクロファイハーフィルター

によるDNA の捕捉

フィル多一洗浄 (70\%冾ェターール)

DNA の溶出扰よび RNase A

処理（フィルターの破砕）

DNA ら回収 (エタノール沈激)

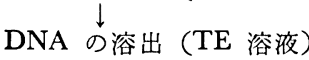

B

溶出 DNA (TE 溶液)

制限醉素処理 (EcoRI, $37^{\circ} \mathrm{C}, 18$ 時間)

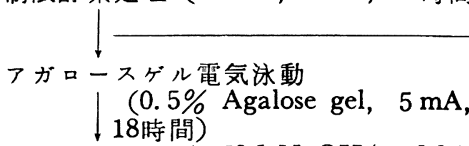

アルカリ処理 $(0.5 \mathrm{M} \mathrm{NaOH} / 1.5 \mathrm{M} \mathrm{NaCl})$

$\downarrow$ 中和 (1M Tris. $\mathrm{HCl}(\mathrm{pH} 8.0) /$

$$
\text { 1. } 5 \mathrm{M} \mathrm{NaCl} \text { ) }
$$

サザントランスファー (18時間)

ベーキシク $\left(80^{\circ} \mathrm{C}, 2\right.$ 時間 $)$

$\downarrow$

プレハイプリダイゼーション $\left(42^{\circ} \mathrm{C} 4\right.$ 時間 $)$

ヘイプリダイゼーション $\left(42^{\circ} \mathrm{C}\right.$ 18時間 $)$

検出
20\%FCS-RPMI 1640 とし，これをセラムチューブ（住 友ベークライト: MS 4502) に入れ slow freezing $\left(1^{\circ} \mathrm{C} /\right.$ min) でー $80^{\circ} \mathrm{C}$ 超低温冷凍庫内に一晚保存後, 液体窒

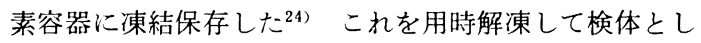
て用いた。

(2) 抗 HTLV-I 抗体の測定

a) ゼラチン粒子凝集法 (PA 法)

抗 HTLV-I 抗体の一次スクリーニングとしてセロデ イア ATLA キット（富士レビオ社）を用いてIkedaら の方法 ${ }^{25}$ により凝集反応を行った。判定は 3 時間判定で 16倍以下を陰性，32倍以上を陽性とし，抗体価は最大血 清希釈倍数で表示した。

b) 間接篮光抗体法 (IF 法)

二次スクリーニングは，HTLV-I感染リンパ球である MT-1 綀胞抗原（鹿児島大学医学部门イルス学教室から 分与）を用いる間接䖝光抗体法 ${ }^{26)}$ により行った. MT-1 細胞は 5-ヨード-2'-デオキシウリジン（以下 ludr：50 $\mu \mathrm{g} / \mathrm{m} l)$ を含む $10 \%$ FCS-RPMI 1640 で3 日間培養に より HTLV-I 関連抗原陽性細胞を誘導i门し, その細胞 浮遊液をPBS で洗浮後, マルチスライドブレート(Flow labs.) に塗抹乾燥後, 冷了セ卜ン固定 (10分間), $-20^{\circ} \mathrm{C}$ で乾燥保存し用時開封して用いた。患者血清 $5 \mu l$ を MT-1 細胞プレートにのせ湿潤箱内で 20 分間反応させ PBS で 3 回洗浄後, 2 次抗体としてィソチオシアン酸 フルオレセイン（以下 FITC）標識抗ヒトIgG (Jackson immunoresearch Labs.) を同様に反応させた. $90 \%$ buffered glycerin (0.05 M Carbohydrate buffer, $\mathrm{pH}$ 9.5) で封入後, 䖝光顕微鏡（オリンパス $\mathrm{BH}-2$ ) 下に螢光陽 性紐胞を検鏡した。

（3）患者末梢血リンパ球 (PBLs) からの HTLV-I プロウイルス DNA の検出

a) PBLs-DNA の迅速抽出法

著者は, HTLV-I プロウイルス DNA の迅速䚲断を 行らために，以下に述べる方法を開発し本研究に応用し た。凍結保存 PBLs を用いて，10\%七ト非働化血清加 RPMI 1640 で 6 日間培養（一次培養），Percoll密度勾

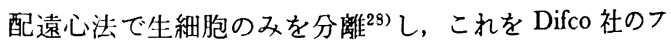
ィトへマグルチニン p (以下 PHA) $5 \mu \mathrm{g} / \mathrm{ml}$ と, 武田 薬品工業社のリコンビナントインターロイキン 2 (以下 r-IL 2) $10 \mathrm{U} / \mathrm{ml}$ を含む $10 \%$ FCS-RPMI 1640 で 20 日間培盖（二次培養）を行い $2 \times 10^{7}$ 個の生細胞標品を 得た。これをPBS で洗浄後, 細胞沈潜を办冷下でよく ほぐし10倍量の溶解用バッファー(10 mM トリス塩酸 ( $\mathrm{pH}$ 7.4), $10 \mathrm{mM}$ EDTA, $150 \mathrm{mM}$ 塩化ナトリウム, $0.4 \% \mathrm{SDS}$ および $1 \mathrm{mg} / \mathrm{m} l$ プロテイナーゼ $\mathrm{K}$ (Merck)) をすばやく加え, $50^{\circ} \mathrm{C}, 3$ 時間軽く振蕩反応させながら DNA 結合性蛋白を消化した，等量のフェノール：クロ ロホルム液 $(1: 1)$ を加え数分間静かに振蕩させたのち $1,400 \mathrm{G}, 10$ 分間遠心，上層の DNA 溶液を分取した. この操作を 3 回繰り返し除蛋白したのち， 2 倍量のエタ 
ノール液 (エタノール：アセテートバッファー( =9:1）を加え白濁液を得た。これをグラスマイクロ ファイバーフィルター (Whatman GF/F) で滤過し, DNA 沈澱を分取した．10倍量の冷70\%エタノールで洗 浄したのち, DNA 沈椬をフィルターごと $1 \mathrm{ml}$ の 10 $\mathrm{mM}$ トリス塩酸 ( $\mathrm{pH} 7.4$ ), $1 \mathrm{mM}$ EDTA (以下 TE 溶夜)にひたし，24 $\mu l$ のリボヌクレアーゼA(SIGMA， デオキシリボヌクレアーゼ不含, $10 \mathrm{mg} / \mathrm{ml}$ ) を加えガ ラス棒でよく挽き, $37^{\circ} \mathrm{C}$ で 3 時間, 保温振蕩後 12,000 G，10分間遠心して DNA を遊離させた。この操作を $37^{\circ} \mathrm{C}, 1$ 時間溶出で 2 回繰り返し、プールした DNA 溶出液にエタノールを加え沈清させた DNA を TE 溶 液に再溶出し精製 DNA を回収した（図1 A). DNA の濃度は $260 \mathrm{~nm}$ の吸光度 $\left(50 \mu \mathrm{g} / \mathrm{ml}=\mathrm{OD}^{260} 1.0\right)$ で, 精製度は OD $260 / 280=1.8$ を指標に評価, 分析した。

b) HTLV-I プロウイルス DNA のドットブロット 法およびサザンブロット法による検出

著者は，ビオチン標識 DNA プローブを用いた非放 射性プロウイルス検出法 ${ }^{29 \sim 30)}$ を応用し, HTLV-I プロ ウイルス DNA の検出を試みた，HTLV-Igag-pol DNA (pATK-32, 癌研究所ウィルス部吉田光昭博上より 分与）をマルチプライム DNA ラベリングシステム (Amersham) ${ }^{31}$,32) により Biotin-lldUTP で標識した. 患 者 PBLs より抽出された DNA $(5 \mu \mathrm{g})$ と制限酵素 EcoRI (Bethesda Research Labs.) 5 ユーットで18 時 間, $37^{\circ} \mathrm{C}$ 反応させ DNA 断片を作製した。これをエタ ノールで沈澱させ, TE 溶液に溶解後以下のごとく電気 泳動によるサザンブロット法33) およびドットブロット 法 ${ }^{34)}$ でプロウイルス DNA を検索した。 DNA 検体を吸 着させ, またはトランスファーしたニトロセルロース膜 を2倍 $\mathrm{SSC}$ で洗浄風乾ののち， $80^{\circ} \mathrm{C}, 2$ 時間焼き付け しDNAフィルターを作製した。これを用いてプレハイ ブリダイゼーションを $42^{\circ} \mathrm{C} ， 4$ 時間行ったのち，上記 のビオチンでラベルした HTLV-I プローブ $(2 \mu \mathrm{g} / \mathrm{ml})$ をハイブリバッグ（コスモバイオ株式会社：S-1001）に いれ， $42^{\circ} \mathrm{C} ， 18$ 時間反応させた。反後, 非放射性核 酸検出システム (BluGENETM: Bethesda Research Labs.) により以下のごとく反応させた，HTLV-I プロ ーブとハイブリダィズさせたフィルターを $0.1 \% \mathrm{SDS}$ を含む 2 倍 $\mathrm{SSC}$ (室温，5分間）で 2 回， $0.1 \% \mathrm{SDS}$ を含む 0.2 倍 $\mathrm{SSC}$ (室温, 5 分間) で 2 回, $0.1 \% \mathrm{SDS}$ を含む 0.16 倍 $\mathrm{SSC}\left(50^{\circ} \mathrm{C}, 15\right.$ 分間) で 2 回洗浄後, 2 倍 SSC で 1 回洗い, バッファー1 (後述) に室温で 1 分間浸した後, ブロッキングのためにバッファー2（後 述）で $65^{\circ} \mathrm{C} ， 1$ 時間ハイブリバッグ内で保温した。ブ ロッキング後 $1 \mu \mathrm{g} / \mathrm{m} l$ のストレプトアビジンアルカリフ オスファターゼコンジュゲート (以下 SA-AP conjugate) を入れ, ゆっくり振蕩させながら常温で 10 分間反応さ せ,つついて, バッファー1 (常温, 10分間) で 2 回,
バッファー3（後述, 常温, 10 分間) で 1 回洗浄後, NBT-BCIP 溶液で発色させた（図 1 B)）。この操作で用 いた試薬の組成は，以下のとおりである。2 倍 SSC : $0.3 \mathrm{M}$ 塩化ナトリウム, $0.03 \mathrm{M}$ クエン酸ナトリウム (pH 7.0) 10 倍 SSC: $1.5 \mathrm{M}$ 塩化ナトリウム, $0.15 \mathrm{M}$ クエン酸ナトリウム（ $\mathrm{pH} 7.0 ）$ プレハイブリダィゼー ション溶液 : $50 \%$ 脱イオン化ホルムアミド(以下 $\operatorname{diFA})$, 5 倍 SSC, 5 倍 Denhardt's 溶液 $\left(0.1 \%(\mathrm{~W} / \mathrm{V})>_{1}\right.$ コ 一ル, $0.1 \%(\mathrm{~W} / \mathrm{V})$ ポリビニルピロリドン, $0.1 \%(\mathrm{~W} /$ $\mathrm{V})$ ウシ血清アルブミン (以下 $\mathrm{BSA}$ ), $25 \mathrm{mM}$ リン酸 ナトリウム $(\mathrm{pH} \mathrm{6.5)}, 0.5 \mathrm{mg} / \mathrm{ml}$ 鮭精鉴 DNA ハイ ブリダイゼーション溶液：45\% diFA，5倍 $\mathrm{SSC}, 1$ 倍 Denhardt's 溶液, $20 \mathrm{mM}$ リン酸ナトリウム $(\mathrm{pH} \mathrm{6.5)}$, $0.2 \mathrm{mg} / \mathrm{ml}$ 鮭精巣 DNA, $5 \%$ 硫酸デキストラン, バッフ

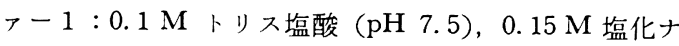
トリウム, バッファー2: $3 \mathrm{~g}(\mathrm{~W} / \mathrm{V}) \mathrm{BSA} / 100 \mathrm{ml}$ ： ッファー1, バッファー $3: 0.1 \mathrm{M}$ トリス塩酸（pH 9.5), $0.1 \mathrm{M}$ 塩化ナトリウム, $50 \mathrm{mM}$ 塩化マグネシウ ム, SA-AP conjugate: $1.0 \mathrm{mg} / \mathrm{m} l$ in $3 \mathrm{M}$ 塩化ナトリ ウム, $1 \mathrm{mM}$ 塩化マグネシウム, $0.1 \mathrm{mM}$ 塩化亜鉛, $30 \mathrm{mM}$ トリエタノールアミン $(\mathrm{pH} \mathrm{7.6)}$

(4) HLA タイピング

凍結保存 PBLs を解凍しBリンホクイック(ベリタス 社) ${ }^{355}$ で $\mathrm{T}$ リンパ球と B リンパ球を分離して HLA タイ ピングの検体とした. HLA タイピングトレーは第 9 回 国際 HLA ワークショップ標準化血清を用いて作製され たものを応用した（鹿児島大学医学部ウイルス学教室よ り分与). HLA タイピングの手技は Terasaki の標準 法 $^{36)}$ に從い HLA-A，-B，-C，-DR，-DQ 抗原について リンパ球賃害テストで行った，HLA 抗体との反応性は 死細胞のエオジン染色性を位相差顕徽鏡（ニコンTMS） で検鏡し，死細胞\%が81〜100\%（スコア 8)，41〜80\% (スコア 6)，21〜40\%（スコア 4)，11〜20\%（スコア 2), $0 \sim 10 \%$ (スコア 1 )の 5 段階で評価し，スコア 6 以 上を陽性反応とした，日本人正常集団の HLA タイプは 第 9 回日本 HLA ワークショップ共同報告書 (1985. 10) により，また，鹿児島県一般健康人集団の HLA タイプ は鹿大ウイルス学教室の研究成績を参考として用いた。

（5）患者 PBLs の細胞性免疫能の分析

患者末梢血中の Tリンパ球サブセットをFITC 標識 モノクローナル抗体 T11, T4, T 8 (Coulter Immunology，USA）でそれぞれ反応させ，フローサイトメトリ - (EPICS CS, Coulter Immunology, USA) で全T細 胞, $\mathrm{CD} 4, \mathrm{CD} 8$ 陽性 Tリンパ球サブセットの比率を 測定した。 レーザーの波長および出力は， $488 \mathrm{~nm}, 500$ $\mathrm{mW}$ を使用した。 また，HTLV-I 抗原に対する特異 T リンパ球応答反応の湘定では, HTLV-I 感染りンパ球 である MT-2 細胞由来 HTLV-I ビリオン抗原 (6.25 ug protein/well)（鹿児島大学医学部ウイルス学教室よ 
表 2 口腔悪性腫瘍患者（非輸血者）における抗 HTLV-I 抗体陽性率

\begin{tabular}{|c|c|c|c|c|c|c|c|c|c|}
\hline \multicolumn{4}{|c|}{ 男 } & \multicolumn{3}{|c|}{ 女 } & \multicolumn{3}{|c|}{ 合 計 } \\
\hline 年 齢 & 対象数 & 陽性数 & 陽性率 $(\%)$ & 対像数 & 陽性数 & 陽性率 $(\%)$ & 対象数 & 陽性数 & 陽性率 $(\%)$ \\
\hline $0 \sim 29$ & 0 & 0 & 0.0 & 0 & 0 & 0.0 & 0 & 0 & 0.0 \\
\hline $30 \sim 39$ & 1 & 0 & 0.0 & 2 & 1 & $50.0^{*}$ & 3 & 1 & 33.3 \\
\hline $40 \sim 49$ & 2 & 0 & 0.0 & 2 & 1 & 50.0 & 4 & 1 & 25.0 \\
\hline $50 \sim 59$ & 13 & 3 & 23.1 & 3 & 0 & 0.0 & 16 & 3 & 18.8 \\
\hline $60 \sim 69$ & 17 & 4 & 23.5 & 6 & 3 & 50.0 & 23 & 7 & 30.4 \\
\hline $70 \sim 79$ & 16 & 3 & 18.8 & 9 & 4 & 44.4 & 25 & 7 & 28.0 \\
\hline $80 \sim 89$ & 3 & 1 & 33.3 & 1 & 0 & 0.0 & 4 & 1 & 25.0 \\
\hline 合 計 & 52 & 11 & $21.2^{* *}$ & 23 & 9 & $39.1^{* *}$ & 75 & 20 & $26.7 * * *$ \\
\hline
\end{tabular}

鹿児島県一般健康人集団（野村紘一郎, 医学研究, 54(7): 34 65, 1984) との比較

$*: \mathrm{p}<0.05$, ** : $\mathrm{p}<0.01, * * *: \mathrm{p}<0.001$

表 3 迅速 DNA 抽出法

\begin{tabular}{lcc}
\hline & 回収率 (c.p.m.) & 回収率 $(\%)$ \\
\hline $\begin{array}{l}\text { 3H-チミジン標識 } \\
\text { MT-2 細胞ライゼート }\end{array}$ & $994,304 \pm 77,973$ c.p.m. & $100(\%)$ \\
\hline フィルター捕捉 DNA & $851,399 \pm 33,222$ c.p.m. & $85.9 \pm 3.4$ \\
\hline $\begin{array}{l}\text { 溶出 DNA* (1, 2, } \\
\text { 回をプール) }\end{array}$ & $565,527 \pm 77,841$ c.p.m. & $56.6 \pm 3.4$ \\
\hline *DNA 精製度 (OD**) & $1.76 \pm 0.06$ & \\
\hline
\end{tabular}

$\mathrm{OD}^{* *}=$ Optical density

り分与）を用いて in vitro 混合培養による ${ }^{3} \mathrm{H}$-チミジン ( $1 \mu \mathrm{Ci} /$ well) の取り込み法 ${ }^{21)}$ で測定した。これを抗 HTLV-I 抗体価ならびに CD 4, CD 8 サブセット比 と関連させ評価した。 また，同様の反応を非特異的 $\mathrm{T}$ 細 胞刺激抗原である PHA $(0.4 \mu \mathrm{g} /$ well $)$ を用いて行っ た。

なお， $\mathrm{T} 11$ は $\mathrm{T}$ 細胞全般， $\mathrm{T} 4$ は helper/inducer $\mathrm{T}$ 細胞, T8 は suppressor/cytotoxic $\mathrm{T}$ 細胞とそれぞれ 反応するマウスモノクローナル抗体である.

\section{III. 研 究 結 果}

（1）鹿児島県における口腔悪性腫瘍患者の属性の検 討

対象患者78例について部位別発生頻度, 年秢, 性差, 病理組織像について調べた（表 1). 部位別発生頻度は, 舌 32 例 $(41.0 \%)$, 口底 17 例 $(21.8 \%)$, 下顎歯肉 10 例 $(12.8 \%)$, 煩粘膜 7 例 $(9.0 \%)$, 口唇 5 例 $(6.4 \%)$, 上 䫇歯肉 4 例 $(5.1 \%)$, その他 3 例 $(3.8 \%)$ であった.

年齢別では， 60 歳代， 70 歳代がそれぞれ 25 例（32.1 \%) で最も多く，次に50歳代 $(21.8 \%), 40$ 歳代・80歳
代 (5.1\%) と続き 30 歳代 (3.8\%) が最も少なかった. 年齢は最低36歳から最高83歳にわたり平均は63.7歳であ った。

性差は男性54例，女性24例で男女比はほぼ 2:1 を示 した。

性差年齢別では男性では60歳代が最も多く，ついで70 歳代, 50歳代と続くが, 女性では70歳代が最も多く, つ いで60歳代，50歳代となっていた。

病理組織学的検索では扁平上皮癌が 74 例 (94.9\%), 悪性リンパ腫 1 例 $(1.3 \%)$, 悪性黑色腫 1 例 $(1.3 \%)$, 腺様敝胞癌 1 例 $(1.3 \%)$, 粘表皮癌 1 例 $(1.3 \%)$ であ った。

（2）口腔悪性腫瘍患者における抗 HTLV-I 抗体の 保有状況

鹿児島県内に本籍を有する口腔悪性腫瘍患者78例のう ち, 抗 HTLV-I 抗体陽性者, すなわち HTLV-I キャ リアは $26.9 \%$ であり，そのらち男性 $22.2 \%$ ，女性 $37.5 \%$ であった。また，非輸血群では抗 HTLV-I 抗体陽性者 が $26.7 \%$ であり，そのうち男性 $21.2 \%$ ，女性 $39.1 \%$ で， 一方輸血群では $33.3 \%$ でありそのうち男性 $50.0 \%$ ，女性 $0.0 \%$ であった（表 2 ）．すなわち，輸血による有意差 


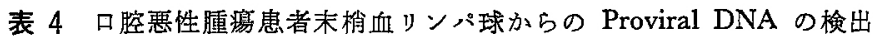

\begin{tabular}{|c|c|c|c|c|c|c|}
\hline \multirow{2}{*}{ ID-No. } & \multirow{2}{*}{ 性別 } & \multirow{2}{*}{ 年龄 } & \multirow{2}{*}{ 診 断 名 } & \multicolumn{2}{|c|}{ 抗 HTLV-I 抗体洒 } & \multirow{2}{*}{ Proviral DNA } \\
\hline & & & & PA 法 & IF 法 & \\
\hline 001 & 男 & 60 & 舌 痁 & 16384 & + & n.t.* \\
\hline 002 & 男 & 62 & 舌 癌 & 1024 & + & - \\
\hline 003 & 男 & 78 & 舌 癌 & 512 & + & n.t: \\
\hline 004 & 男 & 77 & 舌 癌 & 4096 & + & n.t. \\
\hline 005 & 男 & 58 & 舌 癌 & 256 & + & n.t. \\
\hline 021 & 男 & 59 & 口底癌 & 256 & + & + \\
\hline 022 & 男 & 59 & 口底癌 & 2048 & + & + \\
\hline 023 & 男 & 50 & 口底癌 & 4096 & + & n.t. \\
\hline 024 & 男 & 72 & 口底癌 & 4096 & + & - \\
\hline 036 & 男 & 83 & 下顎遒肉癌 & 256 & + & n.t. \\
\hline 040 & 男 & 64 & 煩䅡膜癌 & 32 & + & n.t. \\
\hline 054 & 男 & 62 & 耳下腺癌 & 16384 & + & n.t. \\
\hline 055 & 女 & 36 & 舌 癌 & 1024 & + & + \\
\hline 056 & 女 & 72 & 舌 㾔 & 16384 & + & + \\
\hline 057 & 女 & 72 & 舌 痁 & 8192 & + & n.t. \\
\hline 067 & 女 & 69 & 口底癌 & 4096 & + & n.t. \\
\hline 072 & 女 & 77 & 煩粘膜癌 & 256 & + & n.t. \\
\hline 073 & 女 & 71 & 類粘膜癌 & 4096 & + & n.t. \\
\hline 074 & 女 & 61 & 煩粘膜癌 & 128 & + & n.t. \\
\hline 075 & 女 & 62 & 下唇癌 & 1024 & + & n.t. \\
\hline 076 & 女 & 48 & 上顎薄肉癌 & 8192 & + & + \\
\hline
\end{tabular}

$*$ : n.t. $=$ not tested

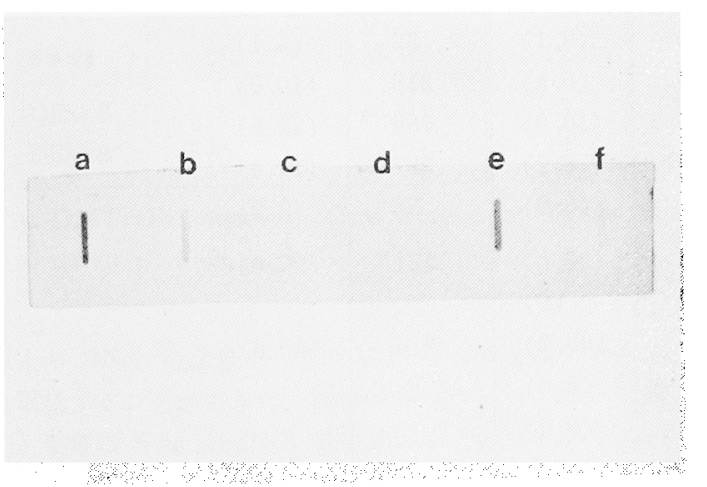

写真 1 ドットブロット法による抗 HTLV-I 抗体 陽性悪性腫瑒患者 (OMT-AC-022) からの Proviral DNA の同定

a: OMT-AC-022 (DNA : $10 \mu \mathrm{g}$ ) b: OMT-AC-022 (DNA : $5 \mu \mathrm{g}$ ) c: OMT-AC-022 (DNA : $1 \mu \mathrm{g}$ ) $\mathrm{d}$ : OMT-AC-022 (DNA : $0.1 \mu \mathrm{g}$ ) e: 陽性コント ロール (MT-2 細胞 DNA： $5 \mu \mathrm{g})$ f: 陰性コント ロー (NIS-DNA : $5 \mu \mathrm{g}$ )
陽性率 $5 / 7$

は認められなかった。抗体洒は32倍〜16,384倍まですり， 平均 2,048 倍であった。抗体を保有する男性患者群のう ち50〜89歳までの年龄層で，鹿児島県一般健康人集団の 抗 HTLV-I 抗体保有率 ${ }^{16)}$ と比較すると, 口陵覀性腫湟

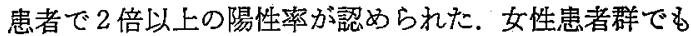
30歳代加ら抗体保有者が認められ，これらを上記一般健 康人集団のそれと比較すると，男性患者同様に 2 倍の陽 性率が認められた。

（3）口腔悪性尰瘍患者の PBLs からの HTLV-I プ ロウイルス DNA の検出

今回，著者が開発したグラスマイクロファイバーを用 いた迅速 DNA 抽出法では陽性対照標品である ${ }^{3} \mathrm{H}$-チミ ジン標識 MT-2 細胞からの DNA の回収率は全細胞 の約半分 (56.6\%) であったが，精製度の高い高分子 DNA が調製される従来法 ${ }^{37)}$ とほぽ同様の DNA 標品を 入手することができた（表 3），口腔悪性腫場患者で抗 HTLV-I 抗体陽性者のらち長期培養可能であった 7 名 の PBLs より上記の方法で DNA を抽出し，ビオチン 標識した非放射性 HTLV-I プローブで HTLV-I プロ ウィルスの検索を行ったところ, 写真 1 に示す如く $1 \mu \mathrm{g}$ 
表 5 口腔悪性腫湯患者の HLA 抗原頻度

\begin{tabular}{|c|c|c|c|c|c|c|}
\hline \multirow{2}{*}{ HLA $^{a}$} & \multicolumn{2}{|c|}{$\begin{array}{c}\mathrm{OMT}(\mathrm{AC}+\mathrm{N})^{\mathrm{b}} \\
(\mathrm{N}=48)\end{array}$} & \multicolumn{2}{|c|}{$\begin{array}{c}\text { Kagoshima } \\
(\mathrm{N}=110)\end{array}$} & \multicolumn{2}{|c|}{$\begin{array}{l}\text { Japanese } \\
(\mathrm{n}=1998)\end{array}$} \\
\hline & No. & $(\%)$ & No. & $(\%)$ & No. & $(\%)$ \\
\hline A 1 & 1 & $(2.1)$ & 1 & $(0.9)$ & 33 & (1.7) \\
\hline A 2 & 25 & $(52.1)$ & 41 & $(37.3)$ & 834 & $(41.7)$ \\
\hline A 3 & 0 & (0) & 2 & $(1.8)$ & 22 & (1.1) \\
\hline A 11 & 8 & (16.7) & 22 & $(20.0)$ & 369 & (18.5) \\
\hline A 24 & 23 & $(47.9)$ & 79 & $(72.8)$ & 1169 & $(58.5)$ \\
\hline A 26 & 16 & $(33.3)$ & 19 & $(17.3)$ & 441 & $(22.1)$ \\
\hline A 31 & 4 & $(8.3)$ & 10 & (9.1) & 321 & (16.1) \\
\hline Aw 33 & 4 & (8.3) & 9 & (8.2) & 283 & $(14.2)$ \\
\hline B 7 & 2 & (4.2) & 12 & (10.9) & 223 & $(11.2)$ \\
\hline B 13 & 1 & (2.1) & 4 & (3.6) & 70 & (3.5) \\
\hline B 17 & 1 & (2.1) & 1 & $(0.9)$ & 36 & (1.8) \\
\hline B 27 & 0 & (0) & 0 & (0) & 17 & $(0.9)$ \\
\hline B 35 & 1 & (2.1) & 26 & $(23.6)$ & 260 & $(13.0)$ \\
\hline B 37 & 0 & (0) & 0 & (0) & & \\
\hline B 38 & 0 & (0) & 1 & $(0.9)$ & 25 & $(1.3)$ \\
\hline В 39 & 1 & (2.1) & 4 & (3.6) & 159 & $(8.0)$ \\
\hline B 44 & 3 & $(6.3)$ & 12 & $(10.9)$ & 271 & $(13.6)$ \\
\hline Bw 46 & 0 & (0) & 2 & $(1.8)$ & 167 & $(8.4)$ \\
\hline Bw 48 & 1 & $(2.1)$ & 7 & (6.4) & 116 & $(5.8)$ \\
\hline B 51 & 7 & $(14.6)$ & 9 & (8. 2) & 289 & (14.5) \\
\hline Bw 52 & 13 & $(27.1)$ & 29 & $(26.4)$ & 333 & (16.7) \\
\hline Bw 54 & 6 & (12.5) & 16 & $(14.5)$ & 284 & $(14.2)$ \\
\hline Bw 55 & 7 & $(14.6)$ & 6 & $(5.5)$ & 110 & (5.5) \\
\hline Bw 56 & 0 & (0) & 1 & $(0.9)$ & 49 & (2.5) \\
\hline Bw 59 & 5 & $(10.4)$ & 10 & (9.1) & 82 & $(4.1)$ \\
\hline $\mathrm{Bw} 60$ & 4 & $(8.3)$ & 6 & $(5.5)$ & 218 & (10.9) \\
\hline Bw 61 & 11 & $(22.9)$ & 11 & $(10.0)$ & 469 & (23.5) \\
\hline Bw 62 & 9 & (18. 8) & 20 & (18.2) & 287 & (14.4) \\
\hline Bw 67 & 1 & $(2.1)$ & 1 & $(0.9)$ & 58 & (2.9) \\
\hline $\mathrm{Cw} 1$ & 20 & $(41.7)$ & 33 & $(30.0)$ & 531 & $(26.6)$ \\
\hline $\mathrm{Cw} 2$ & 0 & (0) & 0 & (0) & & \\
\hline $\mathrm{Cw} 3$ & 24 & $(50.0)$ & 75 & (68.2) & 916 & $(45.8)$ \\
\hline $\mathrm{Cw} 4$ & 4 & $(8.3)$ & 6 & $(5.5)$ & & \\
\hline Cw 5 & 0 & $(0)$ & 1 & $(0.9)$ & & \\
\hline $\mathrm{Cw} 6$ & 0 & (0) & 0 & (0) & & \\
\hline Cw 7 & 4 & $(8.3)$ & 14 & (12.7) & 459 & $(23.0)$ \\
\hline DR 1 & 4 & $(8.3)$ & 12 & $(10.9)$ & 203 & $(10.2)$ \\
\hline DR 2 & 16 & $(33.3)$ & 35 & $(31.8)$ & 581 & (29.1) \\
\hline DR 3 & 1 & $(2.1)$ & 1 & $(0.9)$ & 13 & $(0.7)$ \\
\hline DR 4 & 16 & $(33.3)$ & 39 & $(35.5)$ & 696 & $(34.8)$ \\
\hline DR 5 & 3 & $(6.3)$ & 8 & (7.3) & 253 & (12.7) \\
\hline DRw 6 & 3 & $(6.3)$ & 25 & $(22.7)$ & 318 & $(15.9)$ \\
\hline
\end{tabular}


表 5 つづき

\begin{tabular}{l|r|r|r|r|r|r}
\hline \multirow{2}{*}{ HLA $^{a}$} & \multicolumn{2}{|c|}{$\begin{array}{r}\text { OMT }(\mathrm{AC}+\mathrm{N})^{\mathrm{b}} \\
(\mathrm{N}=48)\end{array}$} & \multicolumn{2}{|c|}{$\begin{array}{r}\text { Kagoshima } \\
(\mathrm{N}=110)\end{array}$} & \multicolumn{2}{|c}{$\begin{array}{c}\text { Japanese } \\
(\mathrm{n}=1998)\end{array}$} \\
\cline { 2 - 7 } & No. & $(\%)$ & No. & $(\%)$ & No. & $(\%)$ \\
\hline DR 7 & 0 & $(0)$ & 1 & $(0.9)$ & & \\
DRw 8 & 20 & $(41.7)$ & 17 & $(15.5)$ & 369 & $(19.8)$ \\
DRw 9 & 13 & $(27.1)$ & 24 & $(12.8)$ & 479 & $(24.0)$ \\
DRw 10 & 0 & $(0)$ & 0 & $(0)$ & 20 & $(1.0)$ \\
DQw 1 & 28 & $(58.3)$ & & & 1122 & $(56.2)$ \\
DQw 3 & 30 & $(62.5)$ & & & 882 & $(44.1)$ \\
TA 10 & 6 & $(12.5)$ & & & 388 & $(19.4)$ \\
Bw 4 & 28 & $(58.3)$ & & & 1040 & $(52.1)$ \\
Bw 6 & 42 & $(87.5)$ & & & 1684 & $(84.3)$ \\
DRw 52 & 25 & $(52.1)$ & & & 996 & $(49.9)$ \\
DRw 53 & 16 & $(33.3)$ & & & 1060 & $(53.1)$ \\
\hline
\end{tabular}

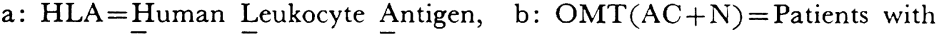
Oral Malignant Tumor (Asymptomatic Carrier+Anti-HTLV-I antibody Negative)

表 6 口腔悪性腫瘍患者の HLA 抗原頻度（鹿児島県一般健康人集団との比校）

\begin{tabular}{|c|c|c|c|c|c|c|c|}
\hline \multirow{2}{*}{ HLA } & \multicolumn{2}{|c|}{$\begin{array}{l}\text { OMTa }^{a} \\
(n=48)\end{array}$} & \multicolumn{2}{|c|}{$\begin{array}{l}\text { Kagoshima } \\
(n=110)\end{array}$} & \multirow{2}{*}{$\mathrm{Pb}^{\mathrm{b}}$} & \multirow{2}{*}{$\mathrm{RR}^{\mathrm{c}}$} & \multirow{2}{*}{$\mathrm{CPd}^{\mathrm{d}}$} \\
\hline & No. & $(\%)$ & No. & $(\%)$ & & & \\
\hline A 26 & 16 & $(33.3)$ & 19 & $(17.3)$ & $<0.05$ & 2.40 & NSe \\
\hline B 35 & 1 & $(2.1)$ & 26 & $(23.6)$ & $<0.005$ & 0.07 & NS \\
\hline Bw 61 & 11 & (22.9) & 11 & $(10.0)$ & $<0.05$ & 2.68 & \\
\hline DRw 6 & 3 & $(6.3)$ & 25 & $(22.7)$ & $<0.025$ & 0.23 & NS \\
\hline DRw 8 & 20 & (41.7) & 17 & (15.5) & $<0.0005$ & 3.84 & $<0.05$ \\
\hline
\end{tabular}

a: $\mathrm{OMT}=$ Patients with Oral Malignant Tumor, b:P=Yates' correction, $\mathrm{c}: \mathrm{RR}=$ relative risk, $\mathrm{d}: \mathrm{CP}=$ corrected $\underline{\mathrm{p}}$ value, e: $\mathrm{NS}=\underline{\text { not }}$ significant

以上の DNA 検体量で HTLV-I プロウィルスの存在 を確認することができた。陽性コントロール（MT-2 細 胞）を含め $5 \mu \mathrm{g}$ の DNA 量を用いると, プロウイルス をほぼ確実に検出できることから，他の症例についても $5 \mu \mathrm{g}$ の DNA を標準検体量として実験に用いた。その 結果, 7 例の抗 HTLV-I 抗体陽性者中 5 例からプロウ イルスが検出された（表 4 ）.

（4）口腔悪性腫瘍患者に関連する HLA の検索

鹿児島県在住の口腔覀性腫瘍患者は HTLV-I の潜伏 感染を高率に受けていることが上記の抗体調査ならびに プロウィルスの検索から明らかとなった。そこで，口腔 覀性腫瘍の発症と HTLV-I 感受性に関する宿主側素因
の関与を検索する目的で, 48例の口腔悪性腫瘍患者を対 象として HLA タイピングを行い，鹿児島県一般健康人 集団 (Kagoshima) ならびに日本人一般集団 (Japanese) の HLA と比較検討した（表 5 ). HLA-A，-B，-C のク ラス I 抗原の分布では鹿児島県一般健康人集団に比し有 意差を認めなかったが，HLA-DR 抗原のうち HLADRw 8 抗原が口腔悪性腫瘍患者群で有意に高く検出さ れた.（鹿児島県一般健康人集団との比較: $\mathrm{RR}=3.84$, $\chi^{2}=12.80$, corrected $\mathrm{P}<0.05$ )（表 6). 次に, 口腔悪 性腫瘍患者の抗 HTLV-I 抗体保有率との関係を調べる ために，口腔悪性腫县患者48例の HLA タイプで比較的 多く検出された抗原型について，HTLV-I キャリアロ 
表 7 口腔悪性腫瘍患者の HLA 抗原頻度 (OMT (AC) とOMT (N) との比較)

\begin{tabular}{l|r|c|r|r|c}
\hline \multirow{2}{*}{ HLA } & \multicolumn{2}{|c|}{$\begin{array}{c}\text { OMT(AC) } \\
(\mathrm{n}=19)\end{array}$} & \multicolumn{2}{|c|}{$\begin{array}{c}\text { OMT(N) } \\
(\mathrm{n}=29)\end{array}$} & \multirow{2}{*}{$\mathrm{p}^{\mathrm{c}}$} \\
\cline { 2 - 5 } & No. & $(\%)$ & No. & $(\%)$ & \\
\hline A 24 & 11 & $(57.9)$ & 12 & $(41.4)$ & NS $^{\mathrm{d}}$ \\
Bw 52 & 6 & $(31.6)$ & 7 & $(24.1)$ & NS \\
Bw 60 & 3 & $(15.8)$ & 1 & $(3.4)$ & NS \\
Cw 7 & 3 & $(15.8)$ & 1 & $(3.4)$ & NS \\
DR 5 & 2 & $(10.5)$ & 1 & $(3.4)$ & NS \\
DRw 8 & 9 & $(47.4)$ & 11 & $(37.9)$ & NS \\
DRw 53 & 8 & $(42.1)$ & 8 & $(27.6)$ & NS \\
\hline
\end{tabular}

a: OMT $(\mathrm{AC})=$ Patients with Oral Malignant Tumor (Asymptmatic Carrier), $\mathrm{b}=$ Patients with Oral Malignant Tumor (Anti-HTLV-I antibody Negative), c: $\mathrm{P}=$ Yates' correction, $\mathrm{d}$ : NS= not significant

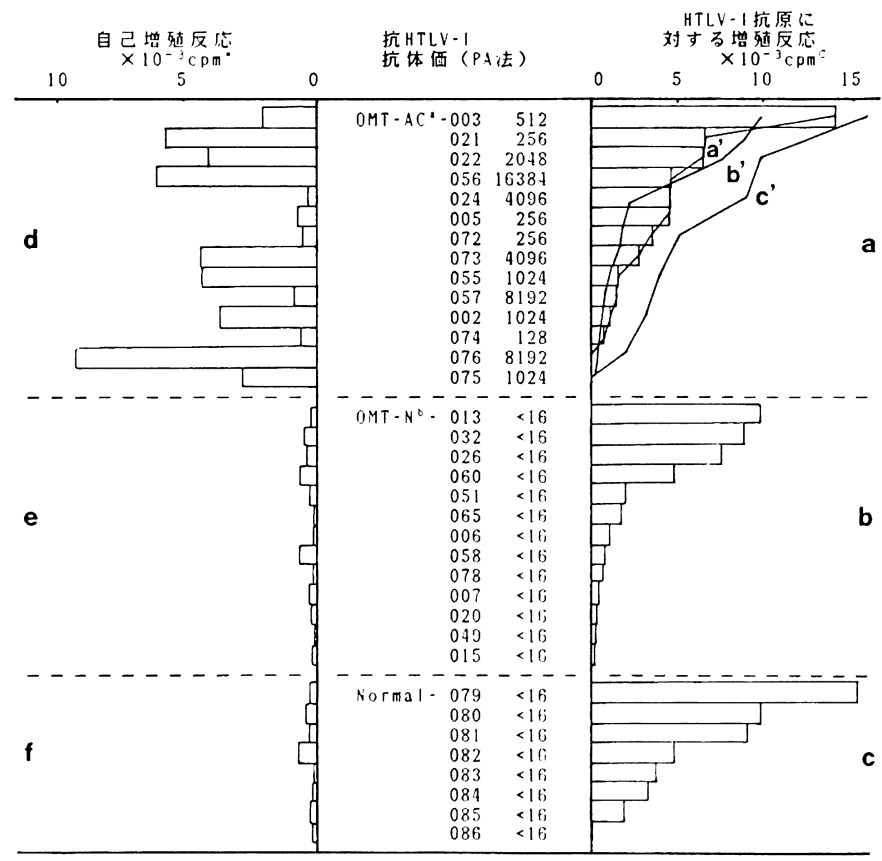

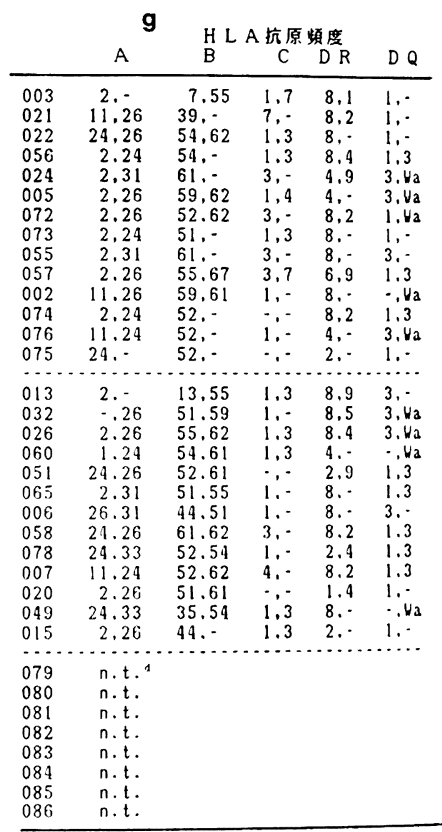

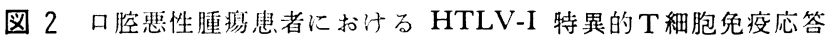

a: OMT-AC $=$ Patients with Oral Malignant Tumor-Asymptomatic Carrier

b: OMT-N=Patients with Oral Malignant Tumor-Anti-HTLV-I antibody Negative

c: $10 \%$ 人血滑加 RPMI-1640 培地で 6 日間堷番, ${ }^{3} \mathrm{H}-$ チミシン16時間パルスによるとりこみ, HTLV-I

ビリオン抗原むるななで行った

d: n.t. $=$ not tested

腔悪性腫瘍患者 (19例) と非キャリアロ腔悪性腫瘍患者 （29例）で比較したところ，いずれの抗原についても有 意差を認めることができなかった（表 7）．したがって，
特定の HLA 型別が HTLV-I に感染しキャリアとなる ことに関連する直接的な証拠は見い出されなかった。

（5）口腔覀性腫瘍患者の HTLV-I に対寸る免疫応 


\section{答性}

口腔悪性腫湯患者の PBLs を精製 HTLV-I ビリオン 抗原と in vitro 培盖し, T細胞の HTLV-I 特異的免疫 応答を測定し非口腔悪性腫瘍患者群のそれらと比較した (図2 a , b , c). HTLV-I キャリア群（図2 a) での HTLV-I 特異的免疫応答反応は HTLV-I 抗原なしで起 こる自己増殖反応 (Autologous proliferative response, 以後 APR と略す ${ }^{21)}$ を差し引いた ${ }^{3} \mathrm{H}$-チミジンの取り 込反量で示した。口腔恶性腫癔患者で HTLV-I キャリ アと非キャリア, 非口腔悪性腫境患者（智歯周用炎，扁

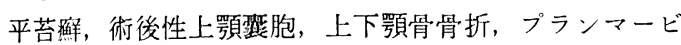
ンソン症候群，唾石症，唾液腺炎，異物による炎症）の 3 群での HTLV-I 特異T細胞免疫応答性の分布を比較 するために，検体の母数をa 群にあわせて换算し投影し たものを図2の a'，b'，c’の折線グラフで示した，a,b， c 群之もに高応答性のものから低応答性のものまで連続 的な分布がみられたが， 3 者の反応分布バターンに少し ずつ偏差傾向が認められた。これに，HTLV-I キャリ アに打注自己增殖反応 (APR) の個人差を勘案して再 評価すると，全体的な反応分布ハターンは $\mathrm{c}^{\prime}>\mathrm{b}^{\prime}>\mathrm{a}^{\prime}$ の 順であった。

HTLV-I キャリア患者群で認められた APR の意義 については, 宇宿, 園田らの ATL 家系および HAM 家系での研究から， HTLV-I キャリアに特発する反応 として報告されている ${ }^{21)}$ が，著者の研究でも APR は HTLV-I 非キャリア群 (e) および非口腔墨性腫痬患 者群（f）ではまったく認められず，HTLV-Iキャリ 了患者群 (d) に打いてのみ認められ，HTLV-I キ+ リアの特性として再確認された。

以上の結果から, HTLV-I に感染した患者群の T 細 胞免疫応答は患者の個体間で高・低の反応性を示し, HTLV-I に対する免疫応答の素因が不均一であること が明らかになったが, 液性免疫応答（抗 HTLV-I 抗体 価）においても同様な個体差が認められた。すなわち, 抗 HTLV-I 抗体価と T細胞応答の反応強度との相関性 をみると, 高応答群 $(>2,500 \mathrm{cpm})$ と低応答群 $(<2,500$ $\mathrm{cpm})$ の間で抗体価はランダムな分布を示し，細胞性免 疫之液性免疫の応答性がそれぞれの患者で分踓して機能 していることが判明した（図了）.

（6）口腔覀性腫焬患者の非特異的免疫応答能と $\mathrm{T}$ 細 胞サブセットの解析

HTLV-I キャリアでは APR の発現があり, 何らか の免疫異常が想定されたが，これがT細胞の全般的機能 にどのように影響しているかを調べるために PHA に対 する非特異反応性を測定した。 その結果, HTLV-I キ +リア患者群では非キャリア患者群に比し，c”>b”>a” のように PHA 反応が低下していることが明らかとなっ た（図 4).PHAに対する応答性はT細胞の機能と密接 に関連するといわれ，HTLV-I キャリアにおける免疫

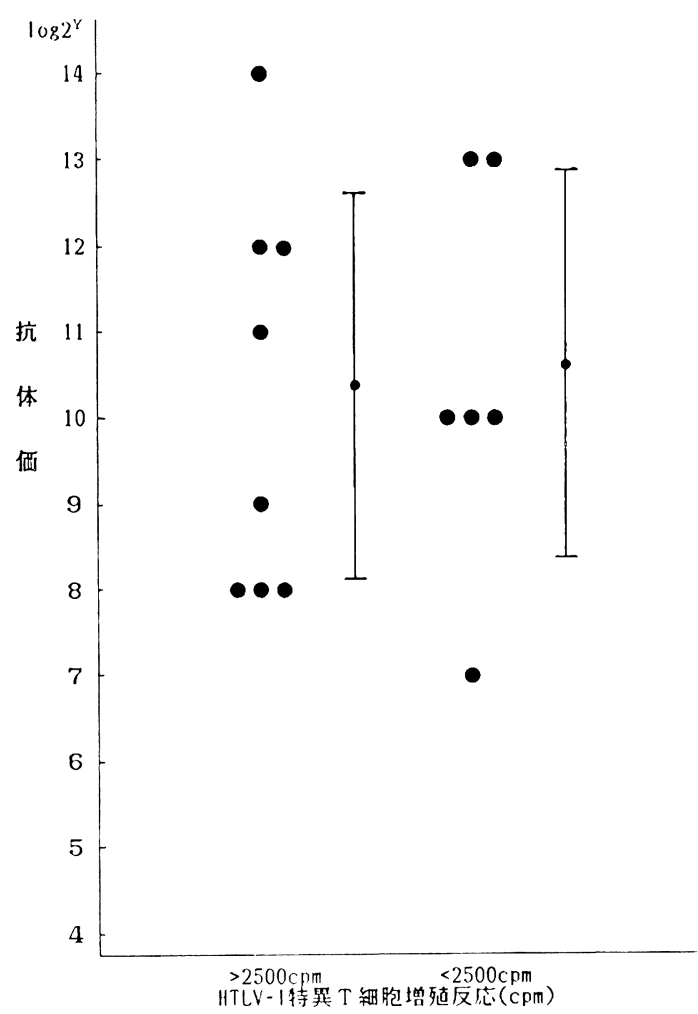

图 3 OMT (AC) に的ける紐胞性免疫能と液性免 疫能の比較

能の低下が示㖫されたので，APR に基づく T細胞サブ セットの增殖を CD $4 / 8$ 比の变化を指標として解析を 行った. HTLV-I キャリア患者 10 例について梌索した 結果, APRによって CD 4/8 比が増加する群 (ID-No 021，072，076）と CD 4/8 比が減少する群 (ID-No. 002，003，022，024，055，056，073）が存在すること が明らかになった（図５）。これを患者の臨床経過と照 合させてみると, CD 4/8 比増加群のうち2 例は初診後 1.0 年 1.5 年で死亡, 1 例は 3 年後頸部転移を認めた。 CD $4 / 8$ 比減少群では 7 例中 5 例は子予後良好であり, 現 在も再発なく生存している. しかし， 2 例は 2 年後に再 発をきたしていた（表 8 ）。したがって，APR 反応で CD 4/8 比が上昇する群は予後不良であり, 逆に CD 4/ 8 比が減少する群では予後良好となることが示され, HTLV-I キャリア患者に抢ける, T細胞サブセットの 動きが口腔腫境の進展, 予後に関連していることが示唆 された。

\section{IV. 総括ならびに考察}

（1）鹿罗島県における口腔恶性腫瘍患者の属性の検 


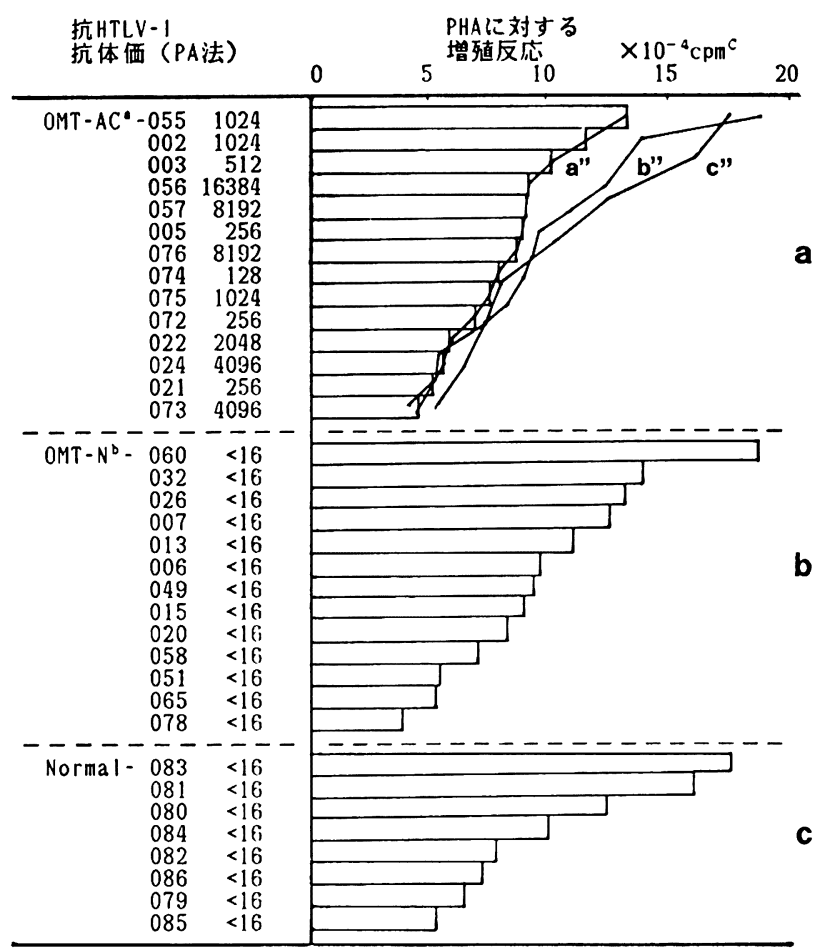

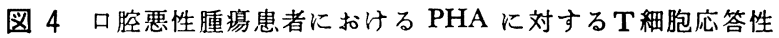

a: $\mathrm{OMT}-\mathrm{AC}=$ Patients with Oral Malignant Tumor-Asymptomatic Carrier

b: OMT-N=Patients with Oral Malignant Tumor-Anti-HTLV-I antibody Negative

c: $10 \%$ 人血清加 RPMI-1640 培地で 6 日間培養, ${ }^{3} \mathrm{H}-$ チミシン 16 時間パルスによるとりこみ, PHA (Phytohemagglutinin P, $0.4 \mu \mathrm{g} /$ well) で行った.

討

一般に口腔癌の発生頻度は全癌腫の $3 \sim 6 \%$ と報告さ れている39).

部位別では，小野ら ${ }^{39)}$ は 300 例中上顎 $45.7 \%$ ，下顎 $24.7 \%$, 舌 $24.4 \%$ と報告し, 一方, 中村ら ${ }^{40}$ は 107 例中 舌 $56.1 \%$, 下䫇歯槽・歯肉 $15.0 \%$, 口底 $13.1 \%$, 頓粘膜 $8.4 \%$ ，上顎歯槽・歯肉 $6.5 \%$ ，硬口蓋 $1.0 \%$ と報告し ている，今回の著者の成績では，舌 $41.0 \%$, 口底 21.8 $\%$ ，下靧歯肉 $12.8 \%$ ，煩粘膜 $9.0 \%$ （表 1）で，中村ら の報告に近く，両者が九州地区の患者を対象としたため ではないかと推測された。また，著者の結果は教室の山

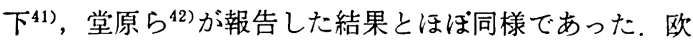
米諸国では舌癌が多数を占めるといわれているが，今回 の患者対象も舌癌が多く欧米型に近かった．

年齡別では60 70歳代が最も多く堂原らの報告 ${ }^{42)}$ とは ぼ同様であった。

性別では, 男:女 $=2: 1$ の比率であったが,これは 一般日本人での成績 $38,41,43)$ 之等しく, 欧米諸国（男：女 $=3: 1)^{44)}$ とは多少異なっていた。病理組織像では, 94.9
\%が扁平上皮癌であり諸家の 報告 $(90 \%)^{39,43,45)}$ とほぼ 同頻度であった。

以上のことより，鹿児島県の口腔覀性腫淘患者は舌癌 が圧倒的に多く，欧米型に近いのが特改的であった。年 齢, 性別, 病理組織像では一般日本人の成績とほ注同様 であった，舌癌を発生させる誘因として，歯牙鋭縁部， 不良補緅物などによる慢性刺激が原因となっている例が 多いが，欧米諸国と鹿児島県との類似点は，その誘因と して，山下 ${ }^{11}$ は患者において飲酒や喫煙者が多かったと 報告しており，これらの疫学的背景が両者を類似させて いるのではないかと思われた。

（2）口腔悪性腫場患者における抗 HTLV-I 抗体の 保有状況

鹿児島県は HTLV-I の高度の浸淫地区として知られ ているが，ここでの一般健康人に护ける抗 HTLV-I 抗 体陽性率は，野村らにより 全年龄層での平均は $11.7 \%$

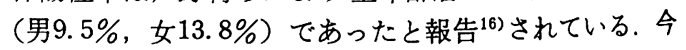
回の結果では, 口腔覀性腫瘍患者のウイルスキャリフは 78 例中 21 例 $(26.9 \%)$, 非輸血群では75例中 20 例 (26.7 


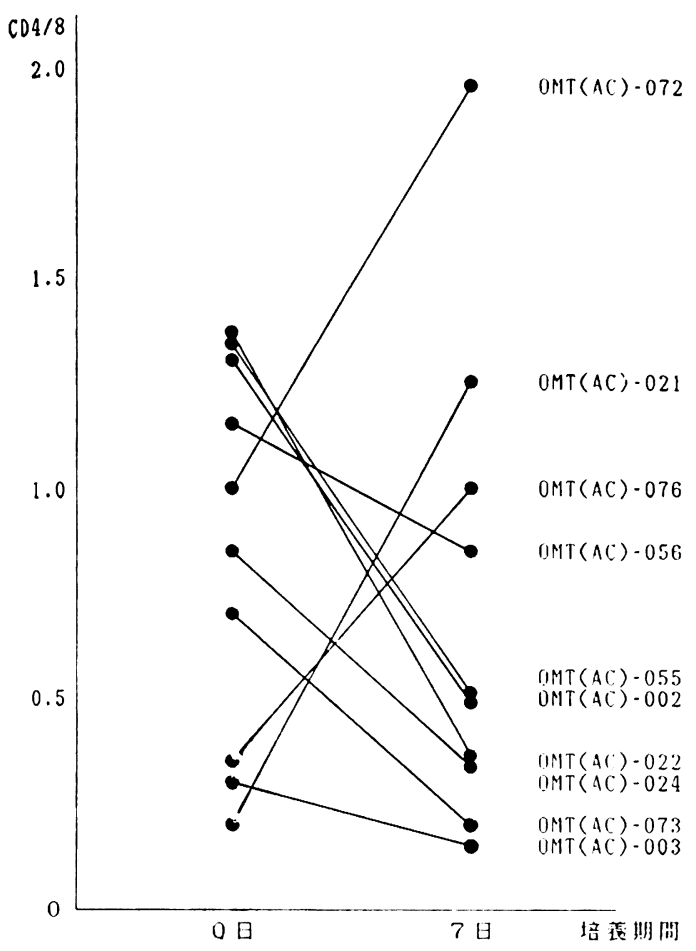

図 $5 \mathrm{OMT}$ ( $\mathrm{AC}$ ) での in vitro 培善後の $\mathrm{T}$ 細胞 サブセットの変化

\%)であり，野村らの成績の約 2.3 倍高率であった（表 2). 男女比は $4: 3$ であり, 野村らの報告 (2:3) と は逆転していた。一般に HTLV-I キャリアは女性のほ らが多いといわれているが，著者の成績はそれと異なっ ていた。これは対象者が口腔恶性腫疸患者であり，男性 のほうが女性よりも多い（男 女＝2:1）ことが影響し ているものと推測された。

したがって，HTLV-I は口腔悪性腫瘍患者において も高度に浸淫し，かつ一般健康人に比べて, HTLV-I 感

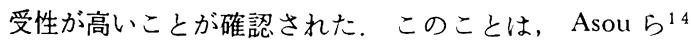
や丸山ら ${ }^{15)}$ が報告しているよ5に, 免疫の機能異常にも 関連していることが示唆された。

（3）口腔悪性腫瘍患者の PBLs からの HTLV-I プ ロウイルス DNA の検出

ATL 患者および HTLV-I ウイルスキャリアからの Proviral DNA の同定には，ラジオアイソトープを用い たサザンブロット法 ${ }^{46)}$ が汎用されているが，一般実験室 での操作が困難である。そこで, 著者は非ラジオアイソ トープ使用による HTLV-I プローブを用いて一般実験 室での操作を迅速かつ平易に行える方法を開発し本研究 に応用した（図１）。この方法の第一の改良点は，DNA の迅速抽出法である。従来法 ${ }^{37)}$ ではフェノール抽出によ
表 $8 \mathrm{OMT}$ (AC) に捕ける in vitro 培着後の $\mathrm{CD} 4 / 8$ 比の変化と予後

\begin{tabular}{c|c|c|c}
\hline \multirow{2}{*}{ ID-No. } & \multicolumn{2}{|c|}{ CD 4/8 比 } & \multirow{2}{*}{ 予 後 } \\
\cline { 2 - 3 } & day 0 & day & \\
\hline 021 & 0.19 & 1.27 & 死 亡 \\
072 & 0.98 & 1.92 & 愐部転移 \\
076 & 0.34 & 1.02 & 死 亡 \\
\hline 002 & 1.28 & 0.51 & 良 好 \\
003 & 0.29 & 0.17 & 良 好 \\
022 & 1.36 & 0.35 & 良 好 \\
024 & 0.83 & 0.32 & 良 好 \\
055 & 1.34 & 0.52 & 頸部転移 \\
056 & 1.15 & 0.87 & 頸部転移 \\
073 & 0.68 & 0.22 & 良 好 \\
\hline
\end{tabular}

る除蛋白と透析によって DNA の精製が行われている が，長時間（2 日間）を要し多試料の操作には不向きて ある，著者の方法は，Vogelstein らのガラスビーズ法 ${ }^{47)}$ を改良したもので，グラスマイクロファイバーフィルタ - (Whatman GF/F) を使用し数時間でしかも多数の 検体を同時に処理することができる点が有利であった。 この方法では，フェノール抽出した粗 DNA 標品をェタ ノールで沈瑖し，グラスマイクロファイバーフィルター に補捉させ，冷エタノール洗浄する 3 段階の操作で残存 フェノールの除去と精製 DNA の回収が可能であり, 全 操作を数時間に短縮できた。しかも，フィルターから溶 出された精製 DNA はプロウィルスの同定検査に十分に 応用できる高分子 DNA であり，回収率も平均 $56.6 \%$ で あり許容される範囲であった（表 3）。第 2 の改良点は, 非放射性で高感度の HTLV-I プローブを作製できた点 であった。 Ward らが開発したビオチン標識法 ${ }^{29,30)}$ とア マルシャムのマルチプライム DNA ラベリングシステ

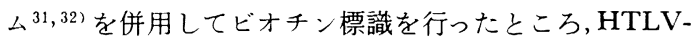
I プロウイルス DNA の検出感度はラジオアィソトー プを用いる常法に比し約 $1 / 10$ 程度であり，一般実験室 での通常の検査に十分に適用できるものであった。デー タは省略したが MT-2 細胞, ATL 患者の PBLs から 今回の方法で抽出した DNA の非放射性プローブを用い たサザンブロット分析にも応用することができた。一般 に, HTLV-I キ+リアでのプロウイルス保有細胞の PBLs 中での割合は1\%以下といわれているので，著者 はプロウイルスの検出率の增加をはかるために, HTLVI 陽性細胞の比率の增幅とウイルスゲノム増加を意図し て，APR を利用した in vitro 培養を行った。つまり， 患者の PBLs を一次培養と二次培坫をあわせて 26 日間 培養した標品を検体とした。この方法でのプロウイルス 
の検出率は， 7 例中 5 例 $(71.4 \%)$ であり満足する結果 であった（表 4 ）。この成績は, 吉田らの ラジオアイソ トープ法での検出率の $100 \%$ に及ばなかったが，ビオチ ンの標識法を改良し，かつ発色の強度と安定化をはかる 方法を検討すれば，ラジオアイソトープなみの検出率が 可能と思われた。

（4）口腔悪性腫瘍患者に関連する HLA の検索

HLA 抗原は，J. Dausset（1958）によって発見され たヒト第 6 染色体の短腕に存在する遺伝子複合体であ り，それにはクラス I (A, B , C) とクラス II (D, DR, DQ）の 2 つがある. HLA の機能は自己の標識抗原，

異物認識，体質の遺伝などに関係し親子の間で優性遗伝 する形質である。したがって, 癌の発症, 予後に関俰す る免疫機序やその他の宿主素因にも関連する機能を有す ることが提唱されている ${ }^{22,49)}$. 著者は, 園田らの提唱す る HTLV-I 感受性と HLA の相関21,48) が口腔悪性腫 瘍患者にも認められ, 癌の発症, 進展, 予後にも関与 しているのではないかと想定して，同患者の HLA の検 索を行った。 その結果，口腔悪性腫瘍患者においては HLA-DRw 8 抗原が有意に高率に検出された（表 6 ）.

この HLA-DRw 8 抗原はクラス II HLA 抗原の一つで あり, マクロファージ, B 細胞, 活性化 $\mathrm{T}$ 細胞上に表出 され免疫の応答と抑制の調節に関与し，癌を排除する免 疫機序にも関連した機能を有する分子である ${ }^{49)}$ 口腔覀 性腫湯患者において HLA-DRw 8 抗原陽性者が高率に みられたことは、ヘルパーインデューサーの機能をもつ $\mathrm{T}$ 細胞 ( $\mathrm{Th} / \mathrm{i})$ が, クラスII HLA 抗原と複合した腫湟 細胞抗原を認識し, 細胞性免疫のエフェクターを誘導す る際に HLA-DRw 8 抗原を表出する個体では Th/i の 認識が弱いためか， あるいは腫盼抗原と HLA-DRw 8 抗原の結合が弱く Th/i の誘導効率が悪いといらメカー ズムによって腫煌を排除する免疫機能が十分に発揮され にくいのではないかと推测された，事実， T細胞性エフ ェクターの拒絶反応が原因とされる習慣性流産患者では HLA-DRw 8 抗原陽性者が祭立って少ないこと海，腎 移植患者の中で生着率がよく拒絶反応が起こりにくいも のは HLA-DRw 8 抗原陽性者であること占が報告され ている。したがって，口腔悪性腫䀛患者に扣ける癌腫の 拒絶反応において，HLA-DRw 8 抗原保有者は同様に 低免疫応答性である可能性が推察される.

今回，著者が明らかにした HLA-DRw 8 抗原と口腔 悪性腫瘍との遺伝的連鎖は, 口腔悪性腫瘍患者のリスク ファクターとしての有用性があり, 前癌病変患者に扣い ては発癌のリスクを把握して予防指針をたてることに活 用することができるかも知れない，本研究を除いては， DR 抗原と口腔悪性腫瘍との相関を確認した研究はな く，著者の研究は有意義な知見を提供したものと思われ る. 今後さらに, 症例数を積み重ね HLA-DRw 8 を指 標とする口腔腫瘍の発症要因の作用機序を明らかにして
いきたい。

一方, 園田らは, ATL 患者, HAM 患者の HLA と 免疫応答の機能を検索して，ATL 患者群は HTLV-I に対して低応答性, HAM 患者群は高応答性であること を示し, 疾病の発症と免疫遺伝学的素因の関連を明らか にした ${ }^{21)}$. 著者は，HTLV-I キャリア口腔悪性腫煌患 者においても同様な相関があるのではないかと考充， HTLV-I キャリア患者, 非キャリア患者, 鹿罗島県一 般健康人集団の三者間に共通する特異な HLA タイプお よび HTLV-I キャリアに特異な HLA タイプを検索し たが，いずれにおいても確認されず， T細胞の免疫応答 とも相関しなかった。しかし，園田らの研究で取り扱わ れたように多数例をもとに精査すれば，口腔悪性腫湯患 者でも HTLV-I に関する高応答性と低応答性の遺伝素 因が発見でき，これが HLA と関連する可能性も否定で きない.

（5）口腔悪性腫㕫患者の HTLV-I に対する免疫応 答性

T細胞は生体において腫瘍排除の免疫エフェクタ ー52 55)として主体をなすものであり，それぞれの機能 をもつT細胞サブセットを分析すれば悪性腫瘍患者の治 療指針の設定，予後の推定などを評価できると思われ る．HTLV-I は CD4 ${ }^{+} \mathrm{T}$ 細胞に感染し年余を経て ATL を起こすが，それにいたる潜伏期においても，し ばしば免疫不全状態を起こすことが知られている. Uchiyama $5^{56)}$ や Morimoto $5^{57)}$ は，ATL 細胞がサ プレッサー細胞として働く可能性を示しており Popovic ら ${ }^{58)}$ は， HTLV-I がヘルパーT 細胞 $\left(\mathrm{CD} 4^{+}\right)$やキラ 一 $\mathrm{T}$ 細胞 $\left(\mathrm{CD}^{+}\right)$に感染し，その機能を変化させる ことを, Mitsuya ら ${ }^{59)}$ は HTLV-I 感染によってキラー $\mathrm{T}$ 細胞の細胞障害機能が消失することを報告している. Katsuki ら ${ }^{(0)}$ は HTLV-I キャリアにおいて EBウィル スに対する細胞性免疫の機能低下があると報告してい る，以上の諸家の研究を総合すると，HTLV-I 感染を らけた患者は細胞性免疫能が全般的に低下していること がうかがえる，一方，加䠲61) に伴う生体変化，環境因子 への暴露などによって起こる発癌の可能性は常に存在し ていると考えられ，T細胞を主役とする生体防御監視系

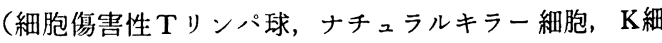
胞など）によって癌化した細胞は排除されているといわ れる。したがって，この $\mathrm{T}$ 細胞の機能低下は癌の進展を 許容し，予後に影響すると思われる 索した鹿児島県の口腔悪性腫瘍患者は，ATL 多発地域 に居住するものが多く HTLV-I 感染によるT細胞の機 能に影響をらけやすい状況にあると思われた。つまり， 加柃，その他の外来因子によって癌化細胞が出現する と，これを排除する $\mathrm{T}$ 細胞機能の低下が背景となって腫 陽発生のリスクを高めているのではないかと推測され た，事実，口腔悪性腫沮患者に HTLV-I が感染すると 
T細胞の免疫応答性は低下傾向を示すことが確認された (図2).この細胞性免疫能の低下は液性免疫能とは独立 して起こり，HTLV-Iキャリアの生体内での免疫応答 の複雑さがらかがわれた（図３）。しかし，口腔悪性腫 瘍患者では PHA 反応の低下（後述）にみられるよ5 に，全般的免疫能の低下傾向が進行しており，HTLV-I の感染はこれをより一層低下させる傾向を示すことか ら，患者の予後に悪影響を及ぼしていることが示唆され た、したがって，治療指針の設定にあたってはこれを十 分考虑する必要があると思われた。

（6）口腔悪性腫瘍患者の非特異的免疫応答能と $\mathrm{T}$ 細 胞サブセットの解析

口腔覀性腫瘍患者の $\mathrm{T}$ 細胞免疫能の低下傾向は非特異 的抗原刺激 (PHA) との反応性において子認められ，そ の傾向は HTLV-I 感染によってさらに増強された（図 4). 一方, HTLV-I キャリアの APR に伴う T 細胞サ ブセットの変化を口腔悪性腫瘍患者でみると, CD4/8 比は症例ごとに異なっていたが，大別して 2 群に分ける ことができた（図 5). APR による CD $4 / 8$ 比の変化 と患者の臨床経過との関係を照合すると, CD 4/8 比増 加群は一般に予後が悪く, CD4/8 比減少群では予後が 良好であった（表 8).ATL患者では CD4/8 比が極端 に高く，HAM 患者では低い21) 前者は予後不良であり 後者は緩徐な進行で致死的ではないことが報告されてい るが，著者の成績ではこれらの予後の推移とよく合致し ていた，CD4/8 比の減少すなわち $\mathrm{CD}^{+}$細胞の増加は CTL 活性をもつ T 細胞サブセットの増加が期待され, 腫瘍細胞を殺傷し予後を好転させる結果となっているの ではないかと考えられた。

ゆえに患者の T細胞サブセット分析は口腔悪性腫堭患 者における予後の判定に寄与する有用な情報を提供する ものと思われた。

\section{V. 結}

語

口腔悪性腫滛患者における HTLV-I の浸淫とそれに 対する免疫応答能, T細胞サブセット, HLA による遗 伝的背景, 発癌と予後について検討し, 以下の結論を得 た.

1 ）鹿児島県における口腔悪性腫瘍患者の属性につい ては, 部位別では舌>口底>下顎雨肉>煩粘膜の順であ った，男女比では $2: 1$, 年齢別では 60〜70 歳代が最も 多く, 病理組織像では扁平上皮癌 $(94.9 \%)$ が多かっ た.

2）口腔覀性腫瘍患者では, 一般健康人に比べて抗 HTLV-I 抗体陽性者が約 2.3 倍多くみられた。男女比 では 4:3 と男性が多かった。

3）今回, 迅速診断法開発のために行ったグラスマイ クロファイバーを利用した DNA 抽出法とビオチン化プ
ローブを用いたドットブロット法では，DNA の回収率 は $56.6 \%$ ，精製度は OD $260 / 280=1.76 \pm 0.06$ で，一 般奏験室での DNA 診断に有用であった。この方法を用 いると，HTLV-I キ+リア 7 例中 5 例から HTLV-I プ ロウイルスを検出でき満足すべき結果が得られた。

4 ）口腔悪性腫瘍患者と対照群を HTLV-I キャリア 口腔悪性腫瘍患者 (OMT (AC)), 非キャリア口腔悪珄 腫瘍患者 (OMT $(\mathrm{N}))$, 鹿児島県一般健康人集団 $(\mathrm{N})$ に分け HLA タイプを比較したところ， 3 者間に共通す る特異な HLA タイプおよび HTLV-I キャリアでの特 異な HLA タイプはみられなかったが, 前 2 者の口腔悪 性腫瘍患者群では HLA-DRw 8 抗原陽性者が有意に高 く検出され $(\mathrm{cp}<0.05)$, 口腔悪性腫瘍の 発症との関連 が示唆された。

5) HTLV-I ビリオン抗原に対する特異応答性は OMT (AC), OMT (N)，(N) 群に颃いて反応分布に 偏差傾向がみられ，N>OMT $(\mathrm{N})>\mathrm{OMT}(\mathrm{AC})$ の順位 で反応強度に差異がみられた。OMT(AC)では HTLVI 感染に特有な APR が14例中 9 例にみられ潜在的な免 疫異常の存在が示唆された。

6) PHA に対する非特異免疫応答性では N>OMT $(\mathrm{N})>\mathrm{OMT}(\mathrm{AC})$ の順に反応強度の低下傾向がみられ， 口腔悪性腫湟患者に拈ける HTLV-I 感染の影響が認め られた。 OMT (AC) での T 細胞サブセット分析では APR に伴って起こる CD4/8 比の変化が増加する群と 減少する群の 2 群に分かれ，前者では患者の予後が悪く 後者では予後良好であった。すなわち, CD4 が減少し， CD8 サブセットが増加する群では癌の進展を抑制する 何らかの免疫能が働いていることが推察された。この結 果をもとに， T細胞サブセットを指標として予後の判定 ができると考えられた。

以上の結果より, HTLV-I は口腔悪性腫瘍発生に直 接作用している可能性は少ないが，間接的な効果として $\mathrm{T}$ 細胞の機能異常を引き起こし, 細胞性免疫能の低下に よる腫瘍の進展, 予後への悪影響が推察された。とく に, $\mathrm{T}$ 細胞サブセット比の個体差は患者の予後に関連し て重要な決定因子であることが明らかにされ，宿主側要 因として注目すべきものであった。これと，HLA-DRw 8 の口腔悪性腫瘍患者での多発との相関について, 今回 の研究では一見関連珄を認めなかったが，さらに症例を 重ね検討を加えたい

稿を終えるにあたり，ご懇切なるご指導とご校閲を賜 わった鹿児島大学楼学部第一口腔外科学教室山下佐英教 授に深甚なる感謝の意を表します。また，直接ご指尊， ご教示，ご校閲をいただいた本大学医学部ウイルス学教 室園田俊郎助教授, 屋教伸治助手, 高橋和郎助手に深甚 なる感謝の意を表します。最後に本学第一口腔外科学教 室員各位に心からの謝意を表します。

な扰，本論文の要旨は，昭和62年 9 月の第51回日本口 
腔外科学会九州地方部会 (北九州), 扰よび昭和 63 年 6 月の第42回日本口腔科学会総会（札幌）において発表し た。

\section{引用文 献}

1) Shaw, M.W.: Human Chromosome Damage by Chemical Agents. Ann Rev Med 21: 4094321970.

2) zur Hausen, H.: The Role of Viruses in Human Tumors. Adv Cancer Res 33: 771071980.

3）菊池郁夫，笹月健彦：癌体質の遗伝。代謝, 臨 時増刊号, 癌 '86 23: 167-174 1986.

4) Bishop, J.M.: Cellular Oncogenes and Retroviruses. Ann Rev Biochem 52: 301-354 1983.

5) Epstein, M.A., Achong, B.G., et al.: Virus Particles in Cultured Lymphoblasts from Burkitt's Lymphoma. Lancet I: 702-703 1964.

6) zur Hausen, H.: Condylomata Acuminata and Human Genital Cancer. Cancer Res 36 : 7941976.

7) Uchiyama, T., Yodoi, J., et al.: Adult T-Cell Leukemia: Clinical and Hematologic Features of 16 Cases. Blood 50: 481-492 1977.

8) Watanabe, T., Seiki, M., et al.. HTLV Type I (U.S. Isolate) and ATLV (Japanese Isolate) Are the Same Species of Human Retrovirus. Virology 133: 238-241 1984.

9) Hinuma, Y., Komoda, H., et al.: Antibodies to Adult T-Cell Leukemia-Virus-Associated Antigen (ATLA) in Sera from Patients with ATL and Controls in Japan: A Nation-Wide Sero-Epidemiologic Study. Int J Cancer 29: 631-635 1982.

10) Saxinger, W., Blattner, W.A., et al.: Human T-Cell Leukemia Virus (HTLV-I) Antibodies in Africa. Science 225: 1473-1476 1984.

11) Blattner, W.A., Kalyanaraman, V.S., et al.: The Human Type-C Retrovirus, HTLV, in Blacks from the Caribbean Region, and Relationship to Adult T-Cell Leukemia/Lymphoma. Int J Cancer 30: 257-264 1982.

12) Osame, M., Matsumoto, M., et al.: Chronic Progressive Myelopathy Associated with Elevated Antibodies to Human T-Lymphotropic Virus Type I and Adult T-Cell Leukemialike Cells. Ann Neurol 21: 117-122 1987.

13) Gessain, A., Barin, F., et al.: Antibodies to Human T-Lymphotropic Virus Type-I in Patients with Tropical Spastic Paraparesis. Lancet II : 407-409 1985.

14) Asou, N., Kumagai, T., et al.. HTLV-I Seroprevalence in Patients with Malignancy. Cancer 58: 903-907 1986.

15）丸山孝士：ヒト T細胞白血病ウイルス感染とヒ
ト悪性腫場の発生. 医学のあゆみ 139: 5985991986.

16) 野村紘一郎：健康人の抗 ATLA (adult T-cell leukemia virus associated antigens) 抗体につ いての研究. 医学研究 54: 34-65 1984.

17）中村正, 山本哲郎, 他：胃㾔に合併した成人 $\mathrm{T}$ 細胞白血病の 1 剖 検例。内科 54: 793-796 1984.

18）酒井正俊，相良勝郎，他：〈すぶり型成人 $\mathrm{T}$ 和 胞白血病 (Smouldering adult T-cell leukemia) を合併した進行胃癌の 1 例: 癌の臨床 30：3013061984.

19）加藤 修, 槞本泰生, 他：化学療法中に胃癌扰 よび肺癌の摘出術が可能であった ATLの 2 症 例. 臨床血液 27：2136-2142 1986.

20）嵨本義範，小野和俊，他：成人 $\mathrm{T}$ 細胞白血病と 他葴器癌を合併した 5 症例. 臨床血液 29: 7237271988.

21) Usuku, K., Sonoda, S., et al.: HLA Haplotype-Linked High Immune Responsiveness Against HTLV-I in HTLV-I-associated Myelopathy: Comparison with Adult T-Cell Leukemia/Lymphoma. Ann Neurol 23: 143-150 1988.

22) Tiwari, J.L. and Terasaki, P.I.. HLA and Disease Associations. Springer-Verlag, New York Berlin Heidelberg Tokyo, 1985, p 148.

23）过 公美：比重遠沈法によるリンパ球の分離, Conray 400-Ficoll 法. 免疫実験操作法A. 第 2 版, 日本免疫学会編，金沢，1976，443-446 頁.

24）黑木登志夫, 佐藤春郎, 他: 細胞の凍結保存 法。医学のあゆみ 69：406-411 1969.

25) Ikeda, M., Fujino, R., et al.: A New Agglutination Test for Serum Antibodies to Adult T-Cell Leukemia Virus. Gann 75: 845-848 1984.

26) Hinuma, Y. and Nagata, K.: Adult T-cell leukemia: Antigen in an ATL cell line and detection of antibodies to the antigen in human sera. Proc Natl Acad Sci 78: 647664801981.

27) Aaronson, S.A. and Stephenson, J.R.: Endogenous Type-C RNA Viruses of Mammalian Cells. Biochim Biophys Acta 458: 323-354 1976.

28) Kurnick, J.T., Gronvik, K., et al.: Long Term Growth in vitro of Human $\mathrm{T}$ Cell Blasts with Maintenance of Specificity and Function. J Immunol 122: 1255-1260 1979.

29) Langer, P.R., Waldrop, A.A., et al.: Enzymatic synthesis of biotin-labeled polynucleotides: Novel nucleic acid affinity probes. Proc Natl Acad Sci. 78: 6633-6637 1981.

30) Leary, J.J., Brigati, D.J., et al.: Rapid and 
sensitive colorimetric method for visualizing biotin-labeled DNA probes hybridized to DNA or RNA immobilized on nitrocellulose: Bioblots. Proc Natl Acad Sci 80: 4045-4049 1983.

31) Feinberg, A.P., Vogelstein, B., et al.. A Technique for Radiolabelling DNA Restriction Endonuclease Fragments to High Specific Activity. Anal Biochem 132: 6-13 1983.

32) Feinberg, A.P., Vogelstein, B., et al.: "A Technique for Radiolabelling DNA Restriction Endonuclease Fragments to High Specific Activity". Addendum. Anal Biochem 137: 2662671984.

33) Southern, E.M.: Detection of Specific Sequences Among DNA Fragments Separated by Gel Electrophoresis. J Mol Biol 98: 503-517 1975.

34) Davis, L.G., Dibner, M.D., et al.: Methods in molecular biology. Elsevier, New York Amsterdam London, 1986, p 147-149.

35）堀胃忠司, 笹野洋子, 他：新しいB B cell 分離 精製法-B lymphokwik の使用一 移植 20: 697-701 1985.

36) Terasaki, P.I., Bernoco. D., et al.. Microdroplet Testing for HLA-A, -B, -C, and -D Antigens. Amer J Clin Pathol 69: 103-120 1978.

37）菅野雅元：高分子 DNA の抽出法。免疫実験操 作法 X II , 日本免疫学会編, 金沢, 1983, 39813986面.

38）渡辺義男，小林敏行，他 .わが教室に扣いて最 近 3 年間に経験せる口腔領域の癌腫および肉腫 について。 日外誌 6: 323-330 1960.

39）小野史郎：顎 - 口腔領域腫瘍 350 例について. 日口外誌 5：102-107 1959.

40）中村社綱, 田代英雄, 他：わが教室10年間の口 腔癌の臨床統計的観察。日口外誌 23：533-539 1977.

41）山下佐英：口腔領域悪性腫瘍の頸部リンパ節転 移に関寸る臨床病理組織学的研究。鹿大医誌 18: 674-700 1966.

42）堂原義美, 川平清秀, 他.わが教室に扣ける過 去10年間の顎口腔領域覀性腫場の臨床統計的観 察. 日口外誌 25：548-558 1979.

43）山城正宏, 藤井信男, 他 : 口腔領域悪性腫瘍の 臨床病理学的研究。第一報 過去 8 年間の臨床 統計的観察。口科誌 32: 110-116 1983.

44) Shedd, D.P., Schmidt, N.L., et al.: A Survey of Tongue Cancer over a Fifteen year Period in a General Hospital. Surg Gyn \& Obst 106: 15-24 1958.

45）足立 尚，飯塚忠彦，他：当科に扣ける過去 10 年間の顎口腔領域覀性腫場の臨床統計的観察. 日口外誌 33：1442-1449 1987.

46) Yoshida, M., Miyoshi, I., et al.: Isolation and characterization of retrovirus from cell lines of human adult $T$-cell leukemia and its implication in the disease. Proc Natl Acad Sci 79: 2031-2035 1982.

47) Vogelstein, B. and Gillespie, D.: Preparative and analytical purification of DNA from agarose. Proc Natl Acad Sci 76: 615-616 1979.

48）罟田俊郎：ATL と HAM の発症の遗伝的振り 分け。実験医学 5：769-772 1987.

49）西村泰治，笹月健彦：HLA の機能。免疫と疾 患 6: 521-527 1983.

50）高見沢 勝，十字猛夫，他：習慣性流座の免疫 療法一母子間の寬容誘導一。感染 炎症 兔疫 17: 259-265 1987.

51）柏木 登：移植免疫に扣ける HLA 抗原の役 割。日本臨床 秋季臨時增刊号 42：786-792 1984.

52）笠井 潔, 今村正克, 他：ヒト胃癌組織に浸潤 する $\mathrm{T}$ 細胞拉よび $\mathrm{T}$ 細胞亜群の免疫組織学的検 索。癌の臨床 29: 981-986 1983.

53）林良夫, 佐藤光信, 他 : 頭頸部癌患者末梢血 リンパ球サブセットの異常—単クローン抗体に よる解析。医学のあゆみ 128: 507-508 1984.

54）瀬山淳：簤口腔領域癌腫患者の細胞性免疫能 に関する砂究。広大茵誌 14：156-166 1982.

55）瀬山淳：顎口腔領域癌腫患者の細胞性免疫能 に関する研究。広大桏誌 14：167-174 1982.

56) Uchiyama, T., Sagawa, K., et al.: Effect of Adult T-Cell Leukemia Cells on Pokeweed Mitogen-Induced Normal B-Cell Differentiation. Clin Immunol Immunopathol 10: 24341978.

57) Morimoto, C., Matsuyama, T., et al.: Functional and Phenotypic Studies et Japanese Adult T Cell Leukemia Cells. J Clin Invest 75: 836-843 1985.

58) Popovic, M., Flomenberg, N., et al.. Alteration of T-Cell Functions by Infection with HTLV-I or HTLV-II. Science 226: 459-462 1984.

59) Mitsuya, H., Guo, H., et al.: Transformation and Cytopathogenic Effect in an Immune Human T-Cell Clone Infected by HTLV-I. Science 223: 1293-1296 1984.

60) Katsuki, T., Katsuki, K., et al.: Immunesuppression in Healthy Carriers of Adult T-Cell Leukemia Retrovirus (HTLV-I): Impairment of T-Cell Control of Epstein-Barr Virus-Infected B-Cells. Jpn J Cancer Res 78: 639-642 1987.

61) Makinodan, T., Kay, M.M.B.: Age Influence on the Immune System. Adv Immunol 29: 287-330 1980.

62) Levy, J.A.: Autoimmunity and Neoplasia. Am J Clin Pathol 62: 258-280 1974. 
63) Stutman, O.: Immunodepression and Malignancy. Adv Cancer Res 22: 261-273 1975.

64) Penn, I., Tumors Arising in Organ Transplant Recipients. Adv Cancer Res 28: 31-61 1978.

65) Purtilo, D.T.: Immune Deficiency Predispos- ing to Epstein-Barr Virus-Induced Lymphoproliferative Diseases: The X-Linked Lymphoproliferative Syndrome as a Model. Adv Cancer Res 34: 279-312 1981. 